
\title{
$\begin{array}{ll}\text { Research Square } & \begin{array}{l}\text { Preprints are preliminary reports that have not undergone peer review. } \\ \text { They should not be considered conclusive, used to inform clinical practice, } \\ \text { or referenced by the media as validated information. }\end{array}\end{array}$
}

\section{The impact of occupational and personal factors on musculoskeletal pain - a cohort study of female teachers, nurses and sonographers}

Inger Arvidsson ( $\sim$ inger.arvidsson@med.lu.se)

Occupational Environmental Medicine https://orcid.org/0000-0002-8069-0819

Jenny Gremark Simonsen

Occupational and Environmental Medicine, Lund University, SE-22185 Lund

Agneta Lindegård Andersson

Institute of Stress Medicine, Carl Skottbergss gata 22B, SE-41319 Göteborg

Jonas Björk

Occupational and Environmental Medicine, Lund University, SE-22185 Lund

Catarina Nordander

Occupational and Environmental Medicine, Lund University, SE-221-85 Lund

\section{Research article}

Keywords: Longitudinal study, musculoskeletal disorders, multivariable model, multisite pain, regional pain

Posted Date: January 15th, 2020

DOI: https://doi.org/10.21203/rs.2.20876/v1

License: (c) (i) This work is licensed under a Creative Commons Attribution 4.0 International License. Read Full License

Version of Record: A version of this preprint was published on September 18th, 2020. See the published version at https://doi.org/10.1186/s12891-020-03640-4. 


\section{Abstract}

\section{Background}

Musculoskeletal pain is common in the general population and constitutes a major public health problem. A large proportion of these conditions may be work related. This study aimed to explore the relative importance of physical, psychosocial and personal factors, for musculoskeletal single- and multisite pain, among women in ordinary professions with a broad variety of occupational exposures.

Methods

A cohort of 1115 women responded to a questionnaire of ergonomic, psychosocial, personal and life-style factors, and musculoskeletal pain (based on frequency and intensity of complaints in nine anatomical sites), at baseline and at followup (mean 28 months later). Sum-scores of ergonomic- and psychosocial factors were created. The importance of the exposures at baseline for multisite pain ( $\geq$ four pain-sites) at follow-up were estimated using ordinal regression. Multiexposure Poisson regression models of exposures at baseline were used for outcomes of single-site pain at follow-up, in the neck, the shoulders, the hands, the lower back and the feet.

\section{Results}

High sum-scores of ergonomic- and psychosocial factors at baseline were of importance for multisite pain at follow-up, although the strongest risk factor was the presence of multisite pain at baseline. There was a large fluctuation in number of pain-sites between the two time-points, on the individual level. Eighteen percent of the study population reported multisite pain both at baseline and at follow-up, while only eleven percent did not report any pain, neither at baseline nor at follow-up. Among the single-site outcomes, a high sum-score of ergonomic factors was a risk factor of pain in the neck, the hands and the feet. A high sum-score of psychosocial factors was a risk factor of neck-and shoulder pain. The strongest risk factor was, however, pain in the actual anatomical site at baseline. Only a few of the personal and life-style factors were of importance for subsequent single- and multisite pain.

\section{Conclusions}

An overwhelming majority of the women in common occupations were affected by musculoskeletal pain. Both ergonomicand psychosocial factors were predictive of single- and multisite pain. The findings points to the need of actions on individual, organizational and societal level.

\section{Background}

Symptoms and diseases in muscles and joints are common in the general population and thus constitute a major public health problem [1]. A large proportion of these symptoms/disorders, regardless of localization, may be work related [2-3]. Increased risk has been demonstrated for both physical and psychosocial factors. A variety of physical exposures, such as constrained postures, high muscular load, monotonously repeated movements, lack of time for recovery and poor workstation layout, have been identified as possible physical risk factors [3-7]. Further, in the previous scientific literature some evidence for an association between musculoskeletal disorders, and various psychosocial factors such as lack of job control, low decision latitude, and high job demands have been established [8-9]. With respect to medical personnel, at least two systematic reviews focusing on medical staff have reported an association between high psychosocial demand and low job control and musculoskeletal complaints/disorders in lower back, neck, shoulders and knees [10-11]. Moreover, the impact of perceived stress on the development of chronic musculoskeletal pain has been scrutinized in a recent systematic review. The results revealed that available evidence support the etiologic role of perceived stress in the development of chronic spinal pain, with an effect size ranging from low to medium [12]. Besides the occupational factors, 
personal and life-style factors such as age, obesity, smoking, and lack of physical activity in leisure time [13-14], may be of importance for the development of pain.

Musculoskeletal pain tends to come and go [15], with varying intensities, but can also develop into a persistent and severe condition. Pain may be localized to one single anatomical body site, but may also occur in several sites simultaneously, i.e. multisite pain [16]. The consequences, in terms of medical consumption, and absenteeism and restrictions at work, have been found to depend on how many body regions that are affected [17].

However, there are still inconsistencies in the literature about the strengths of evidence for the longitudinal relationship between many of these identified risk factors, and musculoskeletal pain $[8,18]$. Most of the studies performed are still cross-sectional and have consequently limited value for studying causal relationships.

Hence, the aim of this study was to further explore the relative importance of physical, psychosocial and personal factors, in longitudinal associations with multisite musculoskeletal pain, as well as for pain in specific anatomical sites. The study population consists of females in ordinary professions in the public sector, with a broad variety of occupational exposures. Cross-sectional results from the same study group have previously been presented and reported by Arvidsson and coworkers in 2016 [19].

\section{Methods}

Study design

Questionnaires were directed to women in five occupational groups [teachers (Te), anaesthetic nurses (AnN), theatre nurses (TN), assistant nurses (AsN), and sonographers (Sg)] at baseline and at follow-up.

Ten items of self-assessed occupational exposures and personal factors at baseline were analysed in relation to reported musculoskeletal pain at follow up. The experience of pain was collected for nine anatomical sites. The importance of the potential risk factors was analysed in relation to multisite pain, i.e. the number of affected pain-sites, as well as for singlesite pain in the neck, the shoulders, the hands, the lower back and the feet, respectively.

Study population

At baseline, 1591 female employees from 49 public schools, 22 surgical departments and 45 sonography departments in Sweden participated in the study [19]. The inclusion criteria were work at least $50 \%$ of fulltime during a period of at least three months before fulfilling the baseline questionnaire. The participants responded to a questionnaire that included questions on ergonomic-, psychosocial-, personal- and life-style factors and musculoskeletal pain from nine anatomical sites. At baseline, we also performed clinical examinations as well as technical measurements of the physical workload among subgroups of the participants ( $n=485$ and $n=60$, respectively) [19]. The questionnaires were administered at baseline (November 2008 - October 2012) and at follow-up (November 2011 - March 2015) with a follow-up period of mean 28 months (range 20-40 months). The questionnaires at both baseline and at follow-up were sent out to subsets that altered between the various employee categories, in order to make the length of the follow-up period similar. The length of the follow-up periods was for TE mean 29 (range 20-36 months) months, for the surgical staff mean 27 (range 20-40 months) months and for SG mean 29 (20-38 months) months.

Out of the 1591 participants at baseline, 1115 (70\%) submitted responses to the follow-up questionnaire (246 Te, $214 \mathrm{AnN}$, 209 TN, 224 AsN and 222 Sg; Table 1). Their mean seniority at baseline were 17 (range 0.25-45) years. The participation rate among the employee categories ranged from $66 \%$ to $76 \%$. 
Table 1

Musculoskeletal pain and sum scores of ergonomic- and psychosocial factors in the total study population at baseline; among the participants at follow-up $(n=1115)$ and among those who dropped out of the study between baseline and follow-up (i.e., "drop-outs"; $N=476)$.

\begin{tabular}{|c|c|c|c|c|c|c|c|c|c|}
\hline & \multirow[b]{2}{*}{ All } & \multicolumn{6}{|c|}{ Musculoskeletal pain at baseline } & \multirow{2}{*}{$\begin{array}{l}\text { Sum score } \\
\text { Ergonomic } \\
\text { factors }\end{array}$} & \multirow{2}{*}{$\begin{array}{l}\text { Sum score } \\
\text { Psychosocia } \\
\text { factors }\end{array}$} \\
\hline & & $\begin{array}{l}\text { Multisite } \\
\text { pain }^{a}\end{array}$ & Neck & Shoulders & Hands & $\begin{array}{l}\text { Lower } \\
\text { back }\end{array}$ & Feet & & \\
\hline & $\mathrm{N}$ & $\%$ & $\%$ & $\%$ & $\%$ & $\%$ & $\%$ & Mean (SD) & Mean (SD) \\
\hline $\begin{array}{l}\text { Included at } \\
\text { follow-up }\end{array}$ & 1115 & 26 & 39 & 44 & 24 & 39 & 17 & $2.5(1.0)$ & $1.3(1.2)$ \\
\hline Teachers & 246 & 21 & 40 & 34 & 16 & 38 & 11 & $1.6(0.8)$ & $1.8(1.4)$ \\
\hline $\begin{array}{l}\text { Anaesthetic } \\
\text { nurses }\end{array}$ & 214 & 21 & 32 & 40 & 20 & 39 & 17 & $2.8(1.0)$ & $1.2(1.2)$ \\
\hline Theatre nurses & 209 & 29 & 39 & 47 & 24 & 42 & 19 & $3.3(0.8)$ & $1.1(1.1)$ \\
\hline Assistant nurses & 224 & 36 & 41 & 47 & 37 & 47 & 26 & $2.9(0.9)$ & $1.3(1.2)$ \\
\hline Sonographers & 222 & 24 & 44 & 53 & 25 & 28 & 12 & $2.3(0.9)$ & $1.0(1.1)$ \\
\hline Drop-outs, all & 476 & 26 & 44 & 46 & 25 & 39 & 16 & $2.5(1.1)$ & $1.5(1.3)$ \\
\hline Non responders & 297 & 23 & 46 & 44 & 24 & 40 & 15 & $2.5(1.1)$ & $1.5(1.3)$ \\
\hline Retired & 59 & 39 & 37 & 44 & 34 & 36 & 24 & $2.4(1.1)$ & $1.4(1.1)$ \\
\hline $\begin{array}{l}\text { Off duty/change } \\
\text { of work }\end{array}$ & 78 & 28 & 47 & 52 & 20 & 39 & 16 & $2.5(1.0)$ & $1.5(1.4)$ \\
\hline Parental leave & 31 & 23 & 45 & 48 & 19 & 32 & 10 & $2.4(1.1)$ & $1.4(1.3)$ \\
\hline Other reason ${ }^{b}$ & 11 & 60 & 27 & 46 & 50 & 40 & 27 & $2.8(1.1)$ & $1.4(1.2)$ \\
\hline a Participants with & four & in-sites & & & & & & & \\
\hline
\end{tabular}

The distribution of musculoskeletal pain and occupational factors at baseline were generally similar among participants and drop-outs $(n=476)$ at follow-up, with two exceptions (Table 1): The drop-outs had, compared to the participants, a higher frequency of neck pain (44\% vs. $39 \%$ ), and a higher sum-score of psychosocial factors [mean 1.5 (SD 1.3) vs. mean 1.3 (SD 1.2)]. The drop-out categories are shown in Table 1.

Work tasks

The teachers (Te) educated children aged 10-15 years, in theoretical subjects in school-years 4-9 of the state school system. Among the surgical staff, the anaesthetic nurses $(\mathrm{AnN})$ prepared the patient for surgery, anesthetized the patient by intubation and checked instruments to ensure that the patient's general health was maintained during surgery. The theatre nurses (TN) was responsible for sterility in the operating theatre and performed, for example, sterile washing of the patient. During surgery, the TN stood beside the surgeon and assisted with instrumentation, for example by holding a surgical retractor to hold the incision open. Assistant nurses (AsN) assisted the other personnel and prepared materials and patients 
for surgery. For example, they opened a variety of packages with different materials, moved trolley carts with X-ray equipment and adjusted the operating lights. All surgical staff ( $\mathrm{AnN}, \mathrm{TN}$ and $\mathrm{AsN}$ ) were involved in turning, lifting and transferring of the patients in the theatre room. The Sonographers $(\mathrm{Sg})$ performed ultrasound examinations of the heart, the blood vessels, or other organs. The Sg sat or stood at the side of the patient, held a transducer in one hand, operated a keyboard with the other and simultaneously, observed a screen. After the examination, the Sg performed analysis of the images at a computer. Additional details of the work tasks and the physical workload among the occupational categories are reported in the baseline-study [19].

Questionnaire

The questionnaire included questions about the physical workload, psychosocial working conditions, personal and lifestyle factors, and musculoskeletal pain. Physical workload: The mechanical exposure index (MEl [20]) comprised 11 items of work postures and movements, and the physical exposure index (PHYI [20]) included seven items concerned with physical activity and lifting. In both scales, the items were answered on a three-point scale; $1:$ "hardly nothing/not at all", 2:"somewhat" or 3:"a great deal". For each scale, the sum of the points (MEI 11-33 possible; PHYI 7-21 possible) was calculated for each individual. The level of mechanical exposure was then defined into four categories (no exposure 11-12 points, low exposure 13-15 points, medium exposure 16-19 points and high exposure 20-33 points). The physical exposure was defined as no exposure 7-8 points, low exposure 9-10 points, medium exposure 11-13 points and high exposure 14-21 points [20]. Further, sensory demands e.g. eye sight, attention, control of body movements and precision, were measured with a five-item subscale from Copenhagen Psychosocial Questionnaire [21]. The questions were answered on a five-pointscale and the mean value in the dimension was calculated for each individual.

A study specific sum score of ergonomic factors, including MEI, PHYI and sensory demands was calculated. For MEI and $\mathrm{PHYl}$ each participant was given one to four points depending on the category of mechanical and physical exposure (from no exposure to high exposure), respectively. For sensory demands the study population was divided into quartiles where each participant got one to four points, from the lowest quartile to the highest. In total the sum of points ranged from 3-12 points. Then the number of categories was reduced into the sum-score of ergonomic factors (3-6 points $=1,7-8$ points $=2$, 9-10 points $=3$ and 11-12 points $=4$ ). The separate results of the dimensions $\mathrm{MEI}, \mathrm{PHYI}$ and sensory demands are given in additional table 1.

The conditions during computer work were assessed by a study-specific question "Are you satisfied with the computer work-station arrangements?" with the options 1: very satisfied (can work comfortably) or rather satisfied, 2: neither satisfied nor dissatisfied, 3: rather dissatisfied or very dissatisfied (uncomfortable/strenuous work).

Psychosocial working conditions: The psychosocial exposure in terms of job demands, job control and job support from co-workers was measured with a Swedish version of the Job Content Questionnaire (JCQ) [22-23]. Job demands concerned nine items of e.g. working pace, hard work, excessive demands, time pressure, conflicting demands, and stressful work. Job control concerned nine items of decision latitude (e.g. influence at work, freedom to decide how work should be done) and skill discretion (e.g. development opportunities, skill and creativity). In the dimension job support, all four items concerning support from co-workers were selected. For each item the responses used a four-point scale, indicating the level of agreement with various statements about conditions at work. The mean value in each dimension was calculated for each individual. Higher numbers indicated higher demands, better control, and better support.

A subset of the Copenhagen Psychosocial Questionnaire [21] was used to measure emotional demands (three items concerning e.g. emotionally difficult situations and emotional affection by the work), demands on hiding emotions (two items), and leadership (eight items concerning planning of work, conflict solving, communication and concern for staff). All questions were answered on a five-point-scale and the mean value in each dimension was calculated for each individual. 
A study-specific sum-score of psychosocial factors was crafted, based on the six dimensions job demands, job control, job support from colleagues, emotional demands, demands of hiding emotions and leadership. For each of the dimensions job demands, emotional demands and demands of hiding emotions, the upper quartile of the study population was given one point, and the remaining participants zero points. For the dimensions job control, job support and leadership, respectively, the lowest quartile of the population got one point and the remaining participants zero points. A sum-score of 0-6 possible points was calculated for each individual. Due to few individuals with five or six points these two groups were merged together, resulting in a sum-score of psychosocial factor with 0-5 possible steps. The separate results of the six dimensions included in the sum-score are given in additional table 1.

The occupational category for each individual was included in the analysis, in order to explain any predictive factors for pain, that were not covered by the questionnaire comprising questions about ergonomic-, psychosocial- and personal factors.

Personal and lifestyle factors: the participants were asked about their age, seniority, height and weight [body mass index, $B M I$, calculated as weight in $\mathrm{kg} /$ height in meters ${ }^{2}$ ]. They were also asked about personal relaxation [24] "How much of your leisure time (except weekends/holidays) do you usually spend for your own relaxation (without special requirements and obligations)?" (1: $\geq 3$ hours/day; 2: 1-2 hours/day; and 3: <1 hour/day), domestic work [24] "How many hours a week do you spend on work in the home that is not paid work, e.g. shopping, cooking, taking care of finances, washing, cleaning, caring for children, maintaining a car, house and garden?" (1: <10 hours/week; 2: 11-20 hours/week; 3: >21 hours/week), physical exercise [24] "Do you spend your leisure time exercising in any kind? Exercise includes sports, fitness training, gymnastics, dancing, walking, cycling, etc., for at least 30 minutes per occasion” (1: twice a week or more; 2: once a week; 3: occasionally or never) and smoking habits (0: never smoked; 1 : ex-smoker of at least six months standing; 2 : smoker, but not daily; 3 : daily smoker). In the analysis, the categories 0-2 were merged into one category of "not daily smokers".

Musculoskeletal pain [19]: The participants were asked about subjective musculoskeletal complaints in nine anatomical sites: the neck, shoulders, elbows, hands, upper back, lower back, hips, knees and feet, during the preceding 12 months, according to the Nordic Questionnaire [26]. For the shoulders, elbows, hands, hips, knees and feet, pain in one or both sides of the body was regarded as one pain-site. In addition, for each anatomical site, information was collected about the frequency of complaints during the past year using a 5-point scale (never, seldom, sometimes, often, or very often [28]) as well as the intensity of complaints on an eleven-point-scale, from 0 (none at all) to 10 (very, very severe [27]). A subject was considered to have considerable musculoskeletal pain (subsequently referred to simply as "pain") if reporting complaints at least "seldom" with an intensity of at least 7 (very severe), or "sometimes" with an intensity of at least 3 (moderate), or "often" or "very often" with an intensity of at least 2 (slight/mild) [19]. The condition was defined separately for each anatomical site.

The number of anatomical sites with pain was calculated for each individual (0-9 possible). Following the suggested classification by Pereira de Fernandes and Burdorf [17], the participants were divided into five categories; 0: no pain; 1: one pain-site; 2: two pain-sites; 3 : three pain-sites and $4: \geq$ four pain-sites. Multisite pain was defined as having pain from four or more sites of pain.

Further, five of the anatomical sites were selected for analysis of single-site pain: the neck, the shoulders, the hands, the lower back and the feet.

Statistical analyses

All statistical analyses were performed with the IBM SPSS software, version 24 (IBM Corp.). P-values $\leq 0.05$ (two-tailed) were considered as statistically significant. 
Prevalence ratios (PRs) and 95\% confidence intervals (Cls) for pain in the neck, shoulders, hands, lower back and feet at follow-up were first estimated in single-exposure Poisson regression models for all variables collected at baseline (in total eleven factors including pain in the actual anatomical site, sum-scores of ergonomic- and psychosocial factors, computer work, age, BMI, personal recovery, domestic work, physical exercise, smoking and occupational category). In the next step, PRs for pain at follow-up were estimated using Poisson regression with multiple exposures (multi-exposure model), without pain at baseline. In the third step, by adjusting the multi-exposure model for pain at baseline we tried to quantify how much of the explanation from different factors concerning pain at follow-up that was not due to associations with pain that were present already at baseline.

Odds ratios (ORs) and 95\% confidence intervals (Cls) for multisite pain at follow-up (number of pain-sites stratified into five categories, i.e. 0, 1, 2, 3 and $\geq 4$ sites) were first estimated in single-exposure ordinal regression models for the eleven occupational and personal factors collected at baseline. In addition, the importance of multisite pain at baseline, for multisite pain at follow-up was estimated. Next, ORs for the multisite pain at follow-up were estimated using multiexposure ordinal regression, without multisite pain at baseline. Finally, the multi-exposure models were adjusted for multisite pain at baseline.

Differences between prevalence of pain at baseline and at follow-up were evaluated with McNemar test.

Due to a high collinearity (strong correlation) between seniority and age, seniority was omitted from the multi-exposure statistical analysis. Seniority is reported as a single-exposure in additional table 1.

The correlation between the difference of multisite pain categories between baseline and follow-up, and the follow-up period (months) was low (Spearmans rho $=0.03)$.

\section{Results}

Changes in the presence of pain between baseline and follow up

Multisite pain, i.e. pain from four or more anatomical sites, was reported by $26 \%$ of the participants at baseline vs. $28 \%$ at follow-up ( $p=0.22$ ). Among those, 182 participants ( $18 \%$ of the study population) reported multisite pain at both occasions (Fig. 1). Eleven percent (117 individuals) did not report any pain-site, neither at baseline nor at follow-up. In a majority of the participants, the number of pain-sites changed between baseline and follow-up, in both directions: thirty one percent reported more pain-sites at follow-up, while $27 \%$ improved.

In the total study population, the prevalence of neck pain increased between baseline and follow-up (39 \% vs. $42 \%$; $p=0.05$; not in table), while for other anatomical sites there were no statistically significant difference between the two time-points.

The Te reported a higher frequency of pain in the feet at follow-up ( $11 \%$ at baseline vs. $18 \%$ at follow-up; $p=0.01$; not in table). The TN reported a higher frequency of neck pain at follow-up than at baseline (47\% vs. $39 \% ; p=0.03)$. The prevalence of lower back pain among AnN decreased at follow-up (30 \% vs. $39 \%$; $=0.03$ ), while it increased among the Sg (39\% vs. $28 \% ; p=0.001)$.

Risk factors for multisite pain

The occupational exposures, i.e. ergonomic- and psychosocial factors, were risk factors for multisite pain at follow-up, with statistically significant associations in both the single- multi- and adjusted multi-exposure models (table 2). The associations between the sum score of ergonomic factors (1-4) and the sum score of psychosocial factors (0, 1, 2 and 3-5) at baseline, and the number of anatomical sites with pain at follow up, are shown in figure 2 and figure 3 , respectively. 
Table 2. Single- and multi-exposure ordinal regression models in the total study population, of associations between selfreported ergonomic-, psychosocial- and personal factors at baseline and musculoskeletal pain (number of pain-sites in five categories) at follow-up, calculated with Ordinal Regression with overall p-values, odds ratios (OR) and 95\% confidence intervals $(\mathrm{Cl})$. In the last step, the multi-exposure model was adjusted for the number of pain-sites at baseline. Results in bold face are statistical significant. 


\begin{tabular}{|c|c|c|c|c|c|c|c|}
\hline & \multicolumn{3}{|c|}{ Single exposure } & \multicolumn{2}{|c|}{$\begin{array}{l}\text { Multi-exposure } \\
(\mathrm{N}=925)\end{array}$} & \multicolumn{2}{|c|}{$\begin{array}{l}\text { Multi-exposure, } \\
\text { adjusted }(\mathrm{N}=911)\end{array}$} \\
\hline & $\mathrm{N}$ & $\mathrm{p}$ & OR (Cl) & $\mathrm{p}$ & $\mathrm{OR}(\mathrm{Cl})$ & $\mathrm{p}$ & $\mathrm{OR}(\mathrm{Cl})$ \\
\hline Pain at baseline ${ }^{a}$ & 1040 & $<0.001$ & & & - & $<0.001$ & \\
\hline \multicolumn{8}{|l|}{ (number of body regions) } \\
\hline 0 & 239 & & 1 & & - & & 1 \\
\hline 1 & 180 & & $\begin{array}{l}2.89 \\
(2.02- \\
4.13)\end{array}$ & & - & & $\begin{array}{l}2.53 \\
(1.70- \\
3.74)\end{array}$ \\
\hline 2 & 191 & & $\begin{array}{l}4.44 \\
(3.13- \\
6.32)\end{array}$ & & & & $\begin{array}{l}3.99 \\
(2.72- \\
5.86)\end{array}$ \\
\hline 3 & 160 & & $\begin{array}{l}10.8 \\
(7.32- \\
15.9)\end{array}$ & & - & & $\begin{array}{l}10.6 \\
(6.95- \\
16.2)\end{array}$ \\
\hline Multisite pain & 270 & & $\begin{array}{l}49.1 \\
(33.3- \\
72.6)\end{array}$ & & - & & $\begin{array}{l}42.9 \\
(27.8- \\
66.4)\end{array}$ \\
\hline $\begin{array}{l}\text { Sum-score of ergonomic factors } \\
(\text { scale })^{a}\end{array}$ & 991 & $<0.001$ & & $<0.001$ & & 0.01 & \\
\hline 1 & 198 & & 1 & & 1 & & 1 \\
\hline 2 & 264 & & $\begin{array}{l}1.48 \\
(1.07- \\
2.07)\end{array}$ & & $\begin{array}{l}1.36 \\
(0.92- \\
2.00)\end{array}$ & & $\begin{array}{l}1.17 \\
(0.79- \\
1.74)\end{array}$ \\
\hline 3 & 304 & & $\begin{array}{l}2.43 \\
(1.75- \\
3.36)\end{array}$ & & $\begin{array}{l}2.09 \\
(1.40- \\
3.13)\end{array}$ & & $\begin{array}{l}1.55 \\
(1.02- \\
2.35)\end{array}$ \\
\hline 4 & 225 & & $\begin{array}{l}2.64 \\
(1.86- \\
3.73)\end{array}$ & & $\begin{array}{l}2.20 \\
(1.39- \\
3.46)\end{array}$ & & $\begin{array}{l}1.67 \\
(1.04- \\
2.70)\end{array}$ \\
\hline $\begin{array}{l}\text { Complaints on computer workstation } \\
\text { arrangements }^{a}\end{array}$ & 1011 & 0.14 & & 0.23 & & 0.93 & \\
\hline Satisfied & 436 & & 1 & & 1 & & 1 \\
\hline Neutral & 329 & & $\begin{array}{l}1.22 \\
(0.95- \\
1.57)\end{array}$ & & $\begin{array}{l}1.36 \\
(1.03- \\
1.81)\end{array}$ & & $\begin{array}{l}1.17 \\
(0.87- \\
1.57)\end{array}$ \\
\hline Dissatisfied & 246 & & $\begin{array}{l}1.20 \\
(0.91- \\
1.59)\end{array}$ & & $\begin{array}{l}1.19 \\
(0.87- \\
1.64)\end{array}$ & & $\begin{array}{l}1.02 \\
(0.73- \\
1.43)\end{array}$ \\
\hline $\begin{array}{l}\text { Sum-score of psychosocial factors } \\
(\text { scale })^{a}\end{array}$ & 1016 & $<0.001$ & & $<0.001$ & & 0.02 & \\
\hline
\end{tabular}




\begin{tabular}{|c|c|c|c|c|c|c|c|}
\hline 0 & 319 & & 1 & & 1 & & 1 \\
\hline 1 & 328 & & $\begin{array}{l}1.46 \\
(1.11- \\
1.92)\end{array}$ & & $\begin{array}{l}1.40 \\
(1.04- \\
1.88)\end{array}$ & & $\begin{array}{l}1.27 \\
(0.94- \\
1.73)\end{array}$ \\
\hline 2 & 190 & & $\begin{array}{l}1.36 \\
(0.99- \\
1.87)\end{array}$ & & $\begin{array}{l}1.37 \\
(0.97- \\
1.96)\end{array}$ & & $\begin{array}{l}1.00 \\
(0.69- \\
1.45)\end{array}$ \\
\hline 3 & 120 & & $\begin{array}{l}2.81 \\
(1.91- \\
4.14)\end{array}$ & & $\begin{array}{l}2.86 \\
(1.88- \\
4.35)\end{array}$ & & $\begin{array}{l}2.02 \\
(1.29- \\
3.14)\end{array}$ \\
\hline 4 & 44 & & $\begin{array}{l}2.51 \\
(1.44- \\
4.35)\end{array}$ & & $\begin{array}{l}3.31 \\
(1.73- \\
6.33)\end{array}$ & & $\begin{array}{l}1.85 \\
(0.91- \\
3.77)\end{array}$ \\
\hline 5 & 15 & & $\begin{array}{l}2.09 \\
(0.84- \\
5.17)\end{array}$ & & $\begin{array}{l}2.84 \\
(1.00- \\
8.01)\end{array}$ & & $\begin{array}{l}1.37 \\
(0.42- \\
4.48)\end{array}$ \\
\hline Age group (years) & 1059 & 0.44 & & 0.62 & & 0.90 & \\
\hline$<40$ & 262 & & 1 & & 1 & & 1 \\
\hline $40-55$ & 515 & & $\begin{array}{l}1.18 \\
(0.91- \\
1.54)\end{array}$ & & $\begin{array}{l}1.12 \\
(0.83- \\
1.50)\end{array}$ & & $\begin{array}{l}1.02 \\
(0.75- \\
1.40)\end{array}$ \\
\hline$>55$ & 282 & & $\begin{array}{l}1.15 \\
(0.85- \\
1.55)\end{array}$ & & $\begin{array}{l}1.19 \\
(0.84- \\
1.68)\end{array}$ & & $\begin{array}{l}1.09 \\
(0.75- \\
1.58)\end{array}$ \\
\hline Body Mass Index (points) ${ }^{b}$ & 1038 & 0.003 & & 0.03 & & 0.41 & \\
\hline$<18.5$ & 11 & & $\begin{array}{l}1.13 \\
(0.45- \\
2.88)\end{array}$ & & $\begin{array}{l}1.29 \\
(0.46- \\
3.64)\end{array}$ & & $\begin{array}{l}1.18 \\
(0.38- \\
3.61)\end{array}$ \\
\hline $18.5-24.9$ & 673 & & 1 & & 1 & & 1 \\
\hline $25.0-29.9$ & 271 & & $\begin{array}{l}1.28 \\
(1.00- \\
1.64)\end{array}$ & & $\begin{array}{l}1.29 \\
(0.98- \\
1.70)\end{array}$ & & $\begin{array}{l}0.95 \\
(0.71- \\
1.27)\end{array}$ \\
\hline$>30$ & 83 & & $\begin{array}{l}2.06 \\
(1.37- \\
3.12)\end{array}$ & & $\begin{array}{l}1.84 \\
(1.18- \\
2.89)\end{array}$ & & $\begin{array}{l}1.44 \\
(0.91- \\
2.29)\end{array}$ \\
\hline Personal recovery time ${ }^{a}$ & 1039 & 0.14 & & 0.55 & & 0.91 & \\
\hline$\geq 3 \mathrm{~h} /$ day & 265 & & 1 & & 1 & & 1 \\
\hline 1-2 h/day & 547 & & $\begin{array}{l}1.16 \\
(0.90- \\
1.51)\end{array}$ & & $\begin{array}{l}1.33 \\
(0.99- \\
1.79)\end{array}$ & & $\begin{array}{l}1.16 \\
(0.85- \\
1.58)\end{array}$ \\
\hline$<1 \mathrm{~h} /$ day & 227 & & $\begin{array}{l}1.26 \\
(0.93- \\
1.72)\end{array}$ & & $\begin{array}{l}1.10 \\
(0.76- \\
1.61)\end{array}$ & & $\begin{array}{l}1.02 \\
(0.68- \\
1.52)\end{array}$ \\
\hline
\end{tabular}




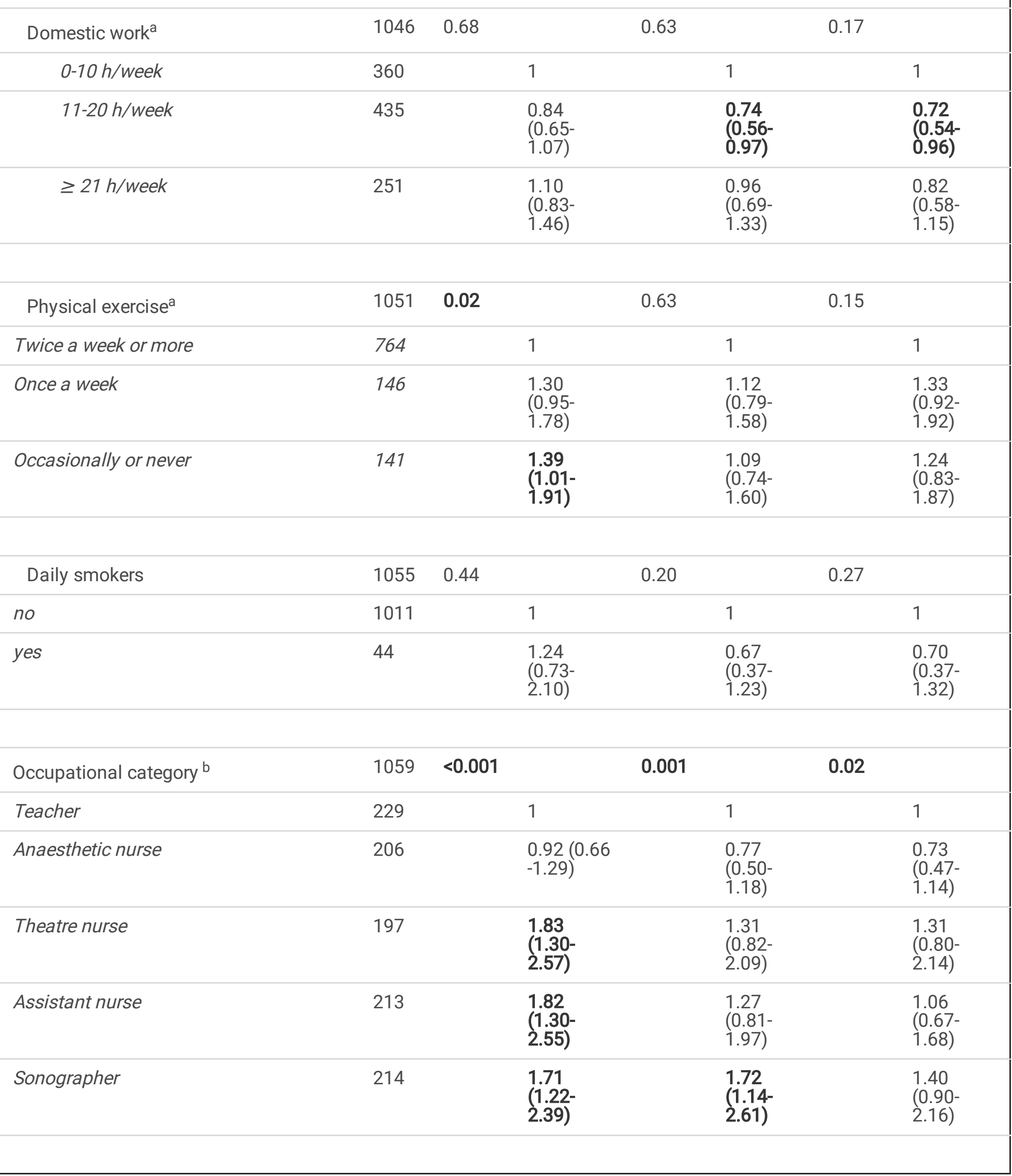

a Overall p-value given as continuous variable

b Overall p-value given as categorical variable "test of model effect"?? 
Among the personal factors, a high BMI and a low frequency of physical exercise were of importance in the single-exposure models (table 2). A high BMI was also a risk factor in the multi-exposure model, but when the model was adjusted for multisite pain at baseline, the importance of a high BMI disappeared. Multisite pain at baseline was the strongest risk factor for multisite pain at follow-up. Further, unknown factors associated with occupational category were of importance for multisite pain, in all of the three statistical models.

Single-exposure models of risk factors for single-site pain

Results from the single-exposure models, for all of the five specific anatomical sites (the neck, the shoulders, the hands, the lower back and the feet), are given in additional Table 2. The main results from these models were that high sum-scores of both ergonomic- and psychosocial factors at baseline were statistically significant risk factors of pain in the neck, the shoulders, the hands and the lower back at follow-up. A high sum-score of ergonomic factor was also a risk factor for pain in the feet. Additional factors that were of importance for subsequent single-site pain were complaints on the computer work station arrangement (pain in the neck), high age (pain in the hands and the feet), a high body-mass index (pain in the feet), lack of time for personal recovery (pain in the neck and the shoulders), a low frequency of physical exercise (pain in the neck and in the lower back) and occupational category (all five anatomical sites). However, having pain in a specific anatomical site at baseline was the strongest predictor of pain in the actual site at follow-up, with PRs ranging from 2.7 to 4.7 between the sites. Much domestic work was a protective factor for hand pain and daily smoking was a protective factor for neck pain.

Multi-exposure models of risk factors for single-site pain

A high sum-score of ergonomic factors at baseline was of importance for pain in the neck, the shoulders, the hands and the feet (Table 3). When adjusting the multi-exposure models for pain in the actual anatomical site at baseline, adverse ergonomic factors remained as a significant risk factor of pain in the neck, the hands and the feet (Table 4). 


\section{Table 3}

Multi-exposure models in the total study population $(n=1115)$ of associations between self-reported ergonomic-, psychosocial- and personal factors at baseline, and musculoskeletal pain in the neck, shoulders, hands, low back and feet at follow-up, calculated with Poisson regression, with overall p-values, prevalence ratio (PR) and 95\% confidence intervals $(\mathrm{Cl})$.

\begin{tabular}{|c|c|c|c|c|c|c|c|c|c|c|c|}
\hline & & \multicolumn{2}{|c|}{ Neck (N = 959) } & \multicolumn{2}{|c|}{$\begin{array}{l}\text { Shoulders }(N= \\
950)\end{array}$} & \multicolumn{2}{|c|}{$\begin{array}{l}\text { Hands }(N= \\
966)\end{array}$} & \multicolumn{2}{|c|}{$\begin{array}{l}\text { Lower back ( } \mathrm{N}= \\
\text { 959) }\end{array}$} & \multicolumn{2}{|c|}{ Feet $(N=967)$} \\
\hline & $\mathrm{N}$ & $\mathrm{p}$ & $\begin{array}{l}\mathrm{PR}(\mathrm{Cl} \\
95 \%)\end{array}$ & $\mathrm{p}$ & $\begin{array}{l}\mathrm{PR}(\mathrm{Cl} \\
95 \%)\end{array}$ & $\mathrm{p}$ & $\begin{array}{l}\mathrm{PR}(\mathrm{Cl} \\
95 \%)\end{array}$ & $\mathrm{p}$ & $\begin{array}{l}\mathrm{PR}(\mathrm{Cl} \\
95 \%)\end{array}$ & $\mathrm{p}$ & $\begin{array}{l}\mathrm{PR}(\mathrm{Cl} \\
95 \%)\end{array}$ \\
\hline $\begin{array}{l}\text { Sum-score of } \\
\text { ergonomic } \\
\text { factors } \\
\text { (scale) }^{a}\end{array}$ & 1046 & $\begin{array}{l}<.01 \\
0.01\end{array}$ & & 0.02 & & 0.001 & & 0.25 & & 0.02 & \\
\hline 1 & 211 & & 1 & & 1 & & 1 & & 1 & & 1 \\
\hline 2 & 283 & & $\begin{array}{l}1.13 \\
(0.88- \\
1.47)\end{array}$ & & $\begin{array}{l}0.97 \\
(0.76- \\
1.23)\end{array}$ & & $\begin{array}{l}1.04 \\
(0.70- \\
1.56)\end{array}$ & & $\begin{array}{l}1.28 \\
(0.97- \\
1.69)\end{array}$ & & $\begin{array}{l}1.14 \\
(0.70- \\
1.84)\end{array}$ \\
\hline 3 & 321 & & $\begin{array}{l}1.30 \\
(1.01- \\
1.69)\end{array}$ & & $\begin{array}{l}1.24 \\
(0.99- \\
1.57)\end{array}$ & & $\begin{array}{l}1.69 \\
(1.16- \\
2.46)\end{array}$ & & $\begin{array}{l}1.45 \\
(1.09- \\
1.91)\end{array}$ & & $\begin{array}{l}1.32 \\
(0.80- \\
2.17)\end{array}$ \\
\hline 4 & 231 & & $\begin{array}{l}1.55 \\
(1.16- \\
2.06)\end{array}$ & & $\begin{array}{l}1.24 \\
(0.95- \\
1.61)\end{array}$ & & $\begin{array}{l}1.65 \\
(1.09- \\
2.51)\end{array}$ & & $\begin{array}{l}1.23 \\
(0.89- \\
1.69)\end{array}$ & & $\begin{array}{l}1.75 \\
(1.03- \\
2.98)\end{array}$ \\
\hline $\begin{array}{l}\text { Complaints on } \\
\text { computer } \\
\text { workstation } \\
\text { arrangements }^{\mathrm{a}}\end{array}$ & 1065 & 0.02 & & 0.05 & & 0.44 & & 0.31 & & 0.38 & \\
\hline Satisfied & 463 & & 1 & & 1 & & 1 & & 1 & & 1 \\
\hline Neutral & 341 & & $\begin{array}{l}1.27 \\
(1.06- \\
1.52)\end{array}$ & & $\begin{array}{l}1.12 \\
(0.94- \\
1.32)\end{array}$ & & $\begin{array}{l}1.03 \\
(0.81- \\
1.32)\end{array}$ & & $\begin{array}{l}1.25 \\
(1.04- \\
1.49)\end{array}$ & & $\begin{array}{l}1.20 \\
(0.88- \\
1.63)\end{array}$ \\
\hline Dissatisfied & 261 & & $\begin{array}{l}1.25 \\
(1.03- \\
1.52)\end{array}$ & & $\begin{array}{l}1.19 \\
(1.00- \\
1.42)\end{array}$ & & $\begin{array}{l}0.92 \\
(0.69- \\
1.23)\end{array}$ & & $\begin{array}{l}1.06 \\
(0.86- \\
1.32)\end{array}$ & & $\begin{array}{l}0.85 \\
(0.58- \\
1.24)\end{array}$ \\
\hline $\begin{array}{l}\text { Sum-score of } \\
\text { psychosocial } \\
\text { factors (scale) } \\
\text { a }\end{array}$ & 1070 & $\begin{array}{l}< \\
0.001\end{array}$ & & $\begin{array}{l}<.001 \\
0.001\end{array}$ & & 0.03 & & 0.003 & & 0.66 & \\
\hline 0 & 337 & & 1 & & & & 1 & & 1 & & 1 \\
\hline
\end{tabular}

a Overall $p$-values are given as continuous variable

b Overall p-values are given as categorical variable "test of model effect" 


\begin{tabular}{|c|c|c|c|c|c|c|c|c|c|c|c|}
\hline & & \multicolumn{2}{|c|}{ Neck ( $N=959)$} & \multicolumn{2}{|c|}{$\begin{array}{l}\text { Shoulders }(N= \\
950)\end{array}$} & \multicolumn{2}{|c|}{$\begin{array}{l}\text { Hands }(N= \\
966)\end{array}$} & \multicolumn{2}{|c|}{$\begin{array}{l}\text { Lower back }(\mathrm{N}= \\
959)\end{array}$} & \multicolumn{2}{|c|}{ Feet $(N=967)$} \\
\hline 1 & 339 & & $\begin{array}{l}1.23 \\
(1.00- \\
1.50)\end{array}$ & & $\begin{array}{l}1.02 \\
(0.85- \\
1.23)\end{array}$ & & $\begin{array}{l}1.43 \\
(1.08- \\
1.88)\end{array}$ & & $\begin{array}{l}1.13 \\
(0.92- \\
1.39)\end{array}$ & & $\begin{array}{l}1.30 \\
(0.94- \\
1.80)\end{array}$ \\
\hline 2 & 203 & & $\begin{array}{l}1.28 \\
(1.02- \\
1.61)\end{array}$ & & $\begin{array}{l}1.17 \\
(0.96- \\
1.43)\end{array}$ & & $\begin{array}{l}1.01 \\
(0.71- \\
1.45)\end{array}$ & & $\begin{array}{l}1.23 \\
(0.98- \\
1.55)\end{array}$ & & $\begin{array}{l}0.84 \\
(0.54- \\
1.31)\end{array}$ \\
\hline 3 & 130 & & $\begin{array}{l}1.41 \\
(1.11- \\
1.78)\end{array}$ & & $\begin{array}{l}1.36 \\
(1.10- \\
1.69)\end{array}$ & & $\begin{array}{l}1.65 \\
(1.19- \\
2.29)\end{array}$ & & $\begin{array}{l}1.38 \\
(1.08- \\
1.77)\end{array}$ & & $\begin{array}{l}1.16 \\
(0.75- \\
1.79)\end{array}$ \\
\hline 4 & 45 & & $\begin{array}{l}1.67 \\
(1.2- \\
2.32)\end{array}$ & & $\begin{array}{l}1.64 \\
(1.24- \\
2.16)\end{array}$ & & $\begin{array}{l}1.37 \\
(0.81- \\
2.31)\end{array}$ & & $\begin{array}{l}1.57 \\
(1.11- \\
2.23)\end{array}$ & & $\begin{array}{l}0.59 \\
(0.21- \\
1.65)\end{array}$ \\
\hline 5 & 16 & & $\begin{array}{l}1.93 \\
(1.26- \\
2.95)\end{array}$ & & $\begin{array}{l}1.78 \\
(1.19- \\
2.67)\end{array}$ & & $\begin{array}{l}1.79 \\
(0.91- \\
3.5)\end{array}$ & & $\begin{array}{l}1.42 \\
(0.84- \\
2.39)\end{array}$ & & $\begin{array}{l}1.49 \\
(0.70- \\
3.18)\end{array}$ \\
\hline $\begin{array}{l}\text { Age group } \\
\text { (years) }^{\mathrm{b}}\end{array}$ & 1115 & 0.85 & & 0.50 & & 0.01 & & 0.75 & & $\begin{array}{l}< \\
0.01\end{array}$ & \\
\hline$<40$ & 267 & & 1 & & 1 & & 1 & & 1 & & 1 \\
\hline $40-55$ & 544 & & $\begin{array}{l}0.95 \\
(0.80- \\
1.14)\end{array}$ & & $\begin{array}{l}0.93 \\
(0.79- \\
1.10)\end{array}$ & & $\begin{array}{l}1.14 \\
(0.86- \\
1.53)\end{array}$ & & $\begin{array}{l}1.08 \\
(0.88- \\
1.32)\end{array}$ & & $\begin{array}{l}2.34 \\
(1.45- \\
3.76)\end{array}$ \\
\hline$>55$ & 304 & & $\begin{array}{l}0.99 \\
(0.80- \\
1.22)\end{array}$ & & $\begin{array}{l}0.89 \\
(0.73- \\
1.09)\end{array}$ & & $\begin{array}{l}1.54 \\
(1.12- \\
2.1)\end{array}$ & & $\begin{array}{l}1.03 \\
(0.82- \\
1.31)\end{array}$ & & $\begin{array}{l}2.20 \\
(1.31- \\
3.71)\end{array}$ \\
\hline $\begin{array}{l}\text { Body Mass } \\
\text { Index (points) }\end{array}$ & 1092 & 0.92 & & 0.12 & & 0.20 & & 0.37 & & $\begin{array}{l}<.01 \\
0.01\end{array}$ & \\
\hline$<18.5$ & 11 & & $\begin{array}{l}1.05 \\
(0.48- \\
2.32)\end{array}$ & & $\begin{array}{l}0.89 \\
(0.43- \\
1.81)\end{array}$ & & $\begin{array}{l}1.55 \\
(0.60- \\
4.01)\end{array}$ & & $\begin{array}{l}0.70 \\
(0.28- \\
1.73)\end{array}$ & & $\begin{array}{l}1.20 \\
(0.18- \\
8.00)\end{array}$ \\
\hline $18.5-24.9$ & 707 & & 1 & & 1 & & 1 & & 1 & & 1 \\
\hline $25.0-29.9$ & 287 & & $\begin{array}{l}1.06 \\
(0.90- \\
1.25)\end{array}$ & & $\begin{array}{l}1.18 \\
(1.01- \\
1.36)\end{array}$ & & $\begin{array}{l}0.96 \\
(0.75- \\
1.23)\end{array}$ & & $\begin{array}{l}1.03 \\
(0.86- \\
1.23)\end{array}$ & & $\begin{array}{l}1.17 \\
(0.86- \\
1.60)\end{array}$ \\
\hline$>30$ & 87 & & $\begin{array}{l}1.02 \\
(0.78- \\
1.33)\end{array}$ & & $\begin{array}{l}1.20 \\
(0.94- \\
1.53)\end{array}$ & & $\begin{array}{l}1.36 \\
(0.98- \\
1.88)\end{array}$ & & $\begin{array}{l}1.21 \\
(0.95- \\
1.55)\end{array}$ & & $\begin{array}{l}1.90 \\
(1.32- \\
2.75)\end{array}$ \\
\hline $\begin{array}{l}\text { Personal } \\
\text { recovery time }\end{array}$ & 1094 & $\begin{array}{l}< \\
0.01\end{array}$ & & 0.01 & & 0.34 & & 0.97 & & 0.81 & \\
\hline a Overall p-value & re giv & I as c & luous & riable & & & & & & & \\
\hline
\end{tabular}




\begin{tabular}{|c|c|c|c|c|c|c|}
\hline & & $\operatorname{Neck}(\mathrm{N}=959)$ & $\begin{array}{l}\text { Shoulders }(N= \\
950)\end{array}$ & $\begin{array}{l}\text { Hands }(\mathrm{N}= \\
966)\end{array}$ & $\begin{array}{l}\text { Lower back }(\mathrm{N}= \\
959)\end{array}$ & Feet $(N=967)$ \\
\hline$\geq 3 \mathrm{~h} /$ day & 281 & 1 & 1 & 1 & 1 & 1 \\
\hline $1-2 \mathrm{~h} /$ day & 577 & $\begin{array}{l}1.27 \\
(1.04- \\
1.55)\end{array}$ & $\begin{array}{l}1.27 \\
(1.05- \\
1.53)\end{array}$ & $\begin{array}{l}1.12 \\
(0.87- \\
1.44)\end{array}$ & $\begin{array}{l}1.06 \\
(0.875- \\
1.28)\end{array}$ & $\begin{array}{l}1.29 \\
(0.93- \\
1.79)\end{array}$ \\
\hline$<1 \mathrm{~h} /$ day & 236 & $\begin{array}{l}1.36 \\
(1.07- \\
1.74)\end{array}$ & $\begin{array}{l}1.35 \\
(1.08- \\
1.70)\end{array}$ & $\begin{array}{l}1.18 \\
(0.83- \\
1.67)\end{array}$ & $\begin{array}{l}1.0 \\
(0.77- \\
1.285)\end{array}$ & $\begin{array}{l}0.98 \\
(0.62- \\
1.57)\end{array}$ \\
\hline $\begin{array}{l}\text { Domestic } \\
\text { work }^{\text {a }}\end{array}$ & 1102 & 0.96 & 0.96 & 0.07 & 0.85 & 0.07 \\
\hline 0-10 h/week & 382 & 1 & 1 & 1 & 1 & 1 \\
\hline $11-20 \mathrm{~h} /$ week & 459 & $\begin{array}{l}0.87 \\
(0.73- \\
1.04)\end{array}$ & $\begin{array}{l}0.89 \\
(0.76- \\
1.05)\end{array}$ & $\begin{array}{l}0.77 \\
(0.61- \\
0.97)\end{array}$ & $\begin{array}{l}0.96 \\
(0.80- \\
1.15)\end{array}$ & $\begin{array}{l}0.78 \\
(0.58- \\
1.06)\end{array}$ \\
\hline$\geq 21 \mathrm{~h} /$ week & 261 & $\begin{array}{l}1.02 \\
(0.84- \\
1.24)\end{array}$ & $\begin{array}{l}1.00 \\
(0.83- \\
1.20)\end{array}$ & $\begin{array}{l}0.78 \\
(0.58- \\
1.04)\end{array}$ & $\begin{array}{l}0.99 \\
(0.80- \\
1.22)\end{array}$ & $\begin{array}{l}0.71 \\
(0.49- \\
1.03)\end{array}$ \\
\hline $\begin{array}{l}\text { Physical } \\
\text { exercise }\end{array}$ & 1107 & 0.83 & 0.30 & 0.48 & 0.56 & 0.29 \\
\hline $\begin{array}{l}\text { Twice a week } \\
\text { or more }\end{array}$ & 807 & 1 & 1 & 1 & 1 & 1 \\
\hline Once a week & 153 & $\begin{array}{l}0.98 \\
(0.80- \\
1.20)\end{array}$ & $\begin{array}{l}0.95 \\
(0.79- \\
1.15)\end{array}$ & $\begin{array}{l}0.88 \\
(0.65- \\
1.20)\end{array}$ & $\begin{array}{l}1.05 \\
(0.85- \\
1.29)\end{array}$ & $\begin{array}{l}0.79 \\
(0.52- \\
1.18)\end{array}$ \\
\hline $\begin{array}{l}\text { Occasionally } \\
\text { or never }\end{array}$ & 147 & $\begin{array}{l}0.99 \\
(0.79- \\
1.23)\end{array}$ & $\begin{array}{l}0.90 \\
(0.71- \\
1.13)\end{array}$ & $\begin{array}{l}0.92 \\
(0.64- \\
1.30)\end{array}$ & $\begin{array}{l}1.05 \\
(0.84- \\
1.31)\end{array}$ & $\begin{array}{l}0.87 \\
(0.56- \\
1.33)\end{array}$ \\
\hline Daily smokers & 1111 & 0.02 & 0.26 & 0.61 & 0.80 & 0.18 \\
\hline no & 1063 & 1 & 1 & 1 & 1 & 1 \\
\hline yes & 48 & $\begin{array}{l}0.57 \\
(0.35- \\
0.93)\end{array}$ & $\begin{array}{l}0.80 \\
(0.54- \\
1.18)\end{array}$ & $\begin{array}{l}0.87 \\
(0.51- \\
1.49)\end{array}$ & $\begin{array}{l}1.05 \\
(0.72- \\
1.53)\end{array}$ & $\begin{array}{l}0.64 \\
(0.33- \\
1.23)\end{array}$ \\
\hline $\begin{array}{l}\text { Occupational } \\
\text { category b }\end{array}$ & 1115 & $<.001$ & $\begin{array}{l}<.001 \\
0 .\end{array}$ & 0.03 & 0.05 & 0.05 \\
\hline Teacher & 246 & 1 & 1 & 1 & 1 & 1 \\
\hline
\end{tabular}

\footnotetext{
a Overall $p$-values are given as continuous variable

b Overall p-values are given as categorical variable "test of model effect"
} 


\begin{tabular}{|c|c|c|c|c|c|c|}
\hline & & $\operatorname{Neck}(\mathrm{N}=959)$ & $\begin{array}{l}\text { Shoulders }(N= \\
950)\end{array}$ & $\begin{array}{l}\text { Hands }(N= \\
966)\end{array}$ & $\begin{array}{l}\text { Lower back }(\mathrm{N}= \\
\text { 959) }\end{array}$ & Feet $(N=967)$ \\
\hline $\begin{array}{l}\text { Anaesthetic } \\
\text { nurse }\end{array}$ & 214 & $\begin{array}{l}0.74 \\
(0.56- \\
0.98)\end{array}$ & $\begin{array}{l}1.05 \\
(0.81- \\
1.37)\end{array}$ & $\begin{array}{l}0.92 \\
(0.59- \\
1.41)\end{array}$ & $\begin{array}{l}0.78 \\
(0.57- \\
1.05)\end{array}$ & $\begin{array}{l}0.75 \\
(0.46- \\
1.24)\end{array}$ \\
\hline Theatre nurse & 209 & $\begin{array}{l}0.99 \\
(0.75- \\
1.31)\end{array}$ & $\begin{array}{l}1.13 \\
(0.86- \\
1.49)\end{array}$ & $\begin{array}{l}1.16 \\
(0.76- \\
1.77)\end{array}$ & $\begin{array}{l}1.19 \\
(0.89- \\
1.58)\end{array}$ & $\begin{array}{l}0.77 \\
(0.47- \\
1.25)\end{array}$ \\
\hline $\begin{array}{l}\text { Assistant } \\
\text { nurse }\end{array}$ & 224 & $\begin{array}{l}0.93 \\
(0.70- \\
1.22)\end{array}$ & $\begin{array}{l}1.12 \\
(0.86- \\
1.45)\end{array}$ & $\begin{array}{l}1.50 \\
(1.03- \\
2.19)\end{array}$ & $\begin{array}{l}1.10 \\
(0.84- \\
1.44)\end{array}$ & $\begin{array}{l}0.86 \\
(0.55- \\
1.36)\end{array}$ \\
\hline Sonographer & 222 & $\begin{array}{l}1.29 \\
(1.02- \\
1.63)\end{array}$ & $\begin{array}{l}1.69 \\
(1.35- \\
2.11)\end{array}$ & $\begin{array}{l}1.38 \\
(0.94- \\
2.02)\end{array}$ & $\begin{array}{l}1.07 \\
(0.82- \\
1.39)\end{array}$ & $\begin{array}{l}0.43 \\
(0.24- \\
0.76)\end{array}$ \\
\hline \multicolumn{7}{|c|}{ a Overall p-values are given as continuous variable } \\
\hline
\end{tabular}


Table 4

Multi-exposure models adjusted for pain at baseline, in the total study population $(n=1115)$ of associations between selfreported ergonomic-, psychosocial- and personal factors at baseline, and musculoskeletal pain in the neck, shoulders, hands, low back and feet at follow-up, calculated with Poisson regression, with overall p-values, prevalence ratio (PR) and 95\% confidence intervals $(\mathrm{Cl})$.

\begin{tabular}{|c|c|c|c|c|c|c|c|c|c|c|c|}
\hline & & \multicolumn{2}{|c|}{$\operatorname{Neck}(N=956)$} & \multicolumn{2}{|c|}{$\begin{array}{l}\text { Shoulders }(N= \\
945)\end{array}$} & \multicolumn{2}{|c|}{$\begin{array}{l}\text { Hands }(N= \\
963)\end{array}$} & \multicolumn{2}{|c|}{$\begin{array}{l}\text { Lower back (N } \\
=956)\end{array}$} & \multicolumn{2}{|c|}{ Feet $(N=966)$} \\
\hline & $\mathrm{N}$ & $p$ & $\begin{array}{l}\mathrm{PR}(\mathrm{Cl} \\
95 \%)\end{array}$ & $\mathrm{p}$ & $\begin{array}{l}\mathrm{PR}(\mathrm{Cl} \\
95 \%)\end{array}$ & $p$ & $\begin{array}{l}\text { PR (Cl } \\
95 \%)\end{array}$ & $p$ & $\begin{array}{l}\mathrm{PR}(\mathrm{Cl} \\
95 \%)\end{array}$ & $p$ & $\begin{array}{l}\mathrm{PR}(\mathrm{Cl} \\
95 \%)\end{array}$ \\
\hline $\begin{array}{l}\text { Pain at } \\
\text { baseline }{ }^{a}\end{array}$ & & $<.001$ & & $<.001$ & & $<.001$ & & $<.001$ & & $\begin{array}{l}<.001 \\
0.00\end{array}$ & \\
\hline no & & & 1 & & 1 & & 1 & & 1 & & 1 \\
\hline yes & & & $\begin{array}{l}3.01 \\
(2.55- \\
3.56)\end{array}$ & & $\begin{array}{l}2.42 \\
(2.07- \\
2.84)\end{array}$ & & $\begin{array}{l}3.49 \\
(2.83- \\
4.32)\end{array}$ & & $\begin{array}{l}2.75 \\
(2.34- \\
3.24)\end{array}$ & & $\begin{array}{l}4.22 \\
(3.25- \\
5.47)\end{array}$ \\
\hline $\begin{array}{l}\text { Sum-score of } \\
\text { ergonomic } \\
\text { factors } \\
\text { (scale) }^{b}\end{array}$ & 1046 & 0.04 & & 0.11 & & $\begin{array}{l}< \\
0.01\end{array}$ & & 0.46 & & 0.04 & \\
\hline 1 & 211 & & 1 & & 1 & & 1 & & 1 & & 1 \\
\hline 2 & 283 & & $\begin{array}{l}1.10 \\
(0.87- \\
1.39)\end{array}$ & & $\begin{array}{l}0.94 \\
(0.75- \\
1.18)\end{array}$ & & $\begin{array}{l}1.01- \\
0.69- \\
1.47)\end{array}$ & & $\begin{array}{l}1.20 \\
(0.94- \\
1.53)\end{array}$ & & $\begin{array}{l}1.04 \\
(0.66- \\
1.64)\end{array}$ \\
\hline 3 & 321 & & $\begin{array}{l}1.15 \\
(0.91- \\
1.46)\end{array}$ & & $\begin{array}{l}1.09 \\
(0.88- \\
1.35)\end{array}$ & & $\begin{array}{l}1.54 \\
(1.08- \\
2.20)\end{array}$ & & $\begin{array}{l}1.29 \\
(1.01- \\
1.64)\end{array}$ & & $\begin{array}{l}1.18 \\
(0.75- \\
1.86)\end{array}$ \\
\hline 4 & 231 & & $\begin{array}{l}1.33 \\
(1.01- \\
1.75)\end{array}$ & & $\begin{array}{l}1.14 \\
(0.88- \\
1.46)\end{array}$ & & $\begin{array}{l}1.44 \\
(0.96- \\
2.16)\end{array}$ & & $\begin{array}{l}1.13 \\
(0.85- \\
1.51)\end{array}$ & & $\begin{array}{l}1.64 \\
(0.96- \\
2.79)\end{array}$ \\
\hline $\begin{array}{l}\text { Complaints on } \\
\text { computer } \\
\text { workstation } \\
\text { arrangements }^{\text {b }}\end{array}$ & 1065 & 0.19 & & 0.39 & & 0.21 & & 0.30 & & 0.52 & \\
\hline Satisfied & 463 & & 1 & & 1 & & 1 & & 1 & & 1 \\
\hline Neutral & 341 & & $\begin{array}{l}1.16 \\
(0.98- \\
1.36)\end{array}$ & & $\begin{array}{l}1.03 \\
(0.88- \\
1.2)\end{array}$ & & $\begin{array}{l}1.05 \\
(0.83- \\
1.32)\end{array}$ & & $\begin{array}{l}1.20 \\
(1.02- \\
1.42)\end{array}$ & & $\begin{array}{l}1.16 \\
(0.88- \\
1.53)\end{array}$ \\
\hline
\end{tabular}

a The frequency of musculoskeletal pain in the different body regions are given in Table 1.

b Overall p-values are given as continuous variable

c Overall p-values are given as categorical variable "test of model effect". 


\begin{tabular}{|c|c|c|c|c|c|c|c|c|c|c|c|}
\hline & & \multicolumn{2}{|c|}{ Neck $(\mathrm{N}=956)$} & \multicolumn{2}{|c|}{$\begin{array}{l}\text { Shoulders }(N= \\
945)\end{array}$} & \multicolumn{2}{|c|}{$\begin{array}{l}\text { Hands }(N= \\
963)\end{array}$} & \multicolumn{2}{|c|}{$\begin{array}{l}\text { Lower back (N } \\
=956)\end{array}$} & \multicolumn{2}{|c|}{ Feet $(N=966)$} \\
\hline Dissatisfied & 261 & & $\begin{array}{l}1.13 \\
(0.95- \\
1.35)\end{array}$ & & $\begin{array}{l}1.07 \\
(0.92- \\
1.25)\end{array}$ & & $\begin{array}{l}0.86 \\
(0.66- \\
1.13)\end{array}$ & & $\begin{array}{l}1.08 \\
(0.88- \\
1.31)\end{array}$ & & $\begin{array}{l}0.88 \\
(0.61- \\
1.27)\end{array}$ \\
\hline $\begin{array}{l}\text { Sum-score of } \\
\text { psychosocial } \\
\text { factors (scale) } \\
\text { b }\end{array}$ & 1070 & 0.01 & & 0.001 & & 0.48 & & 0.13 & & 0.10 & \\
\hline 0 & 337 & & 1 & & 1 & & 1 & & 1 & & 1 \\
\hline 1 & 339 & & $\begin{array}{l}1.16 \\
(0.97- \\
1.38)\end{array}$ & & $\begin{array}{l}1.02 \\
(0.87- \\
1.21)\end{array}$ & & $\begin{array}{l}1.35 \\
(1.05- \\
1.73)\end{array}$ & & $\begin{array}{l}1.03 \\
(0.85- \\
1.24)\end{array}$ & & $\begin{array}{l}1.09 \\
(0.80- \\
1.48)\end{array}$ \\
\hline 2 & 203 & & $\begin{array}{l}1.13 \\
(0.92- \\
1.39)\end{array}$ & & $\begin{array}{l}1.12 \\
(0.93- \\
1.35)\end{array}$ & & $\begin{array}{l}0.92 \\
(0.67- \\
1.27)\end{array}$ & & $\begin{array}{l}1.06 \\
(0.85- \\
1.31)\end{array}$ & & $\begin{array}{l}0.69 \\
(0.46- \\
1.03)\end{array}$ \\
\hline 3 & 130 & & $\begin{array}{l}1.16 \\
(0.94- \\
1.44)\end{array}$ & & $\begin{array}{l}1.25 \\
(1.02- \\
1.52)\end{array}$ & & $\begin{array}{l}1.32 \\
(0.96- \\
1.81)\end{array}$ & & $\begin{array}{l}1.23 \\
(0.98- \\
1.55)\end{array}$ & & $\begin{array}{l}0.89 \\
(0.58- \\
1.36)\end{array}$ \\
\hline 4 & 45 & & $\begin{array}{l}1.35 \\
(0.99- \\
1.82)\end{array}$ & & $\begin{array}{l}1.50 \\
(1.13- \\
2.0)\end{array}$ & & $\begin{array}{l}1.10 \\
(0.67- \\
1.8)\end{array}$ & & $\begin{array}{l}1.27 \\
(0.93- \\
1.73)\end{array}$ & & $\begin{array}{l}0.53 \\
(0.20- \\
1.36)\end{array}$ \\
\hline 5 & 16 & & $\begin{array}{l}2.29 \\
(1.43- \\
3.66)\end{array}$ & & $\begin{array}{l}1.56 \\
(1.08- \\
2.24)\end{array}$ & & $\begin{array}{l}1.34 \\
(0.71- \\
2.54)\end{array}$ & & $\begin{array}{l}0.97 \\
(0.58- \\
1.64)\end{array}$ & & $\begin{array}{l}0.94 \\
(0.46- \\
1.91)\end{array}$ \\
\hline $\begin{array}{l}\text { Age group } \\
\text { (years) }^{c}\end{array}$ & 1115 & 0.69 & & 0.59 & & 0.42 & & 0.54 & & 0.02 & \\
\hline$<40$ & 267 & & 1 & & 1 & & 1 & & 1 & & 1 \\
\hline $40-55$ & 544 & & $\begin{array}{l}0.96 \\
(0.82- \\
1.13)\end{array}$ & & $\begin{array}{l}0.92 \\
(0.79- \\
1.08)\end{array}$ & & $\begin{array}{l}1.03 \\
(0.78- \\
1.37)\end{array}$ & & $\begin{array}{l}1.09 \\
(0.90- \\
1.32)\end{array}$ & & $\begin{array}{l}1.94 \\
(1.21- \\
3.12)\end{array}$ \\
\hline$>55$ & 304 & & $\begin{array}{l}1.03 \\
(0.85- \\
1.25)\end{array}$ & & $\begin{array}{l}0.95 \\
(0.79- \\
1.14)\end{array}$ & & $\begin{array}{l}1.19 \\
(0.87- \\
1.63)\end{array}$ & & $\begin{array}{l}1.01 \\
(0.82- \\
1.25)\end{array}$ & & $\begin{array}{l}1.79 \\
(1.08- \\
2.96)\end{array}$ \\
\hline $\begin{array}{l}\text { Body Mass } \\
\text { Index (points) }\end{array}$ & 1092 & 0.96 & & 0.55 & & 0.26 & & 0.58 & & 0.35 & \\
\hline$<18.5$ & 11 & & $\begin{array}{l}0.83 \\
(0.39- \\
1.78)\end{array}$ & & $\begin{array}{l}0.97 \\
(0.41- \\
2.32)\end{array}$ & & $\begin{array}{l}1.77 \\
(0.70- \\
4.47)\end{array}$ & & $\begin{array}{l}0.76 \\
(0.34- \\
1.68)\end{array}$ & & $\begin{array}{l}1.36 \\
(0.29- \\
6.46)\end{array}$ \\
\hline \multicolumn{12}{|c|}{ a The frequency of musculoskeletal pain in the different body regions are given in Table 1.} \\
\hline \multicolumn{12}{|c|}{ b Overall p-values are given as continuous variable } \\
\hline
\end{tabular}




\begin{tabular}{|c|c|c|c|c|c|c|c|c|c|}
\hline & & Neck & = 956) & $\begin{array}{l}\text { Shou } \\
945)\end{array}$ & rs $(\mathbb{N}=$ & $\begin{array}{l}\text { Hand } \\
963)\end{array}$ & & $\begin{array}{l}\text { Lower back ( } N \\
=956)\end{array}$ & Feet $(\mathrm{N}=966)$ \\
\hline $18.5-24.9$ & 707 & & 1 & & 1 & & 1 & 1 & 1 \\
\hline $25.0-29.9$ & 287 & & $\begin{array}{l}0.99 \\
(0.86- \\
1.15)\end{array}$ & & $\begin{array}{l}1.08 \\
(0.95- \\
1.24)\end{array}$ & & $\begin{array}{l}0.95 \\
(0.75- \\
1.2)\end{array}$ & $\begin{array}{l}1.03 \\
(0.87- \\
1.22)\end{array}$ & $\begin{array}{l}0.95 \\
(0.70- \\
1.29)\end{array}$ \\
\hline$>30$ & 87 & & $\begin{array}{l}1.03 \\
(0.81- \\
1.31)\end{array}$ & & $\begin{array}{l}1.14 \\
(0.91- \\
1.42)\end{array}$ & & $\begin{array}{l}1.26 \\
(0.94- \\
1.71)\end{array}$ & $\begin{array}{l}1.14 \\
(0.92- \\
1.43)\end{array}$ & $\begin{array}{l}1.31 \\
(0.92- \\
1.86)\end{array}$ \\
\hline $\begin{array}{l}\text { Personal } \\
\text { recovery time }\end{array}$ & 1094 & 0.02 & & 0.15 & & 0.31 & & 0.62 & 0.78 \\
\hline$\geq 3$ h / day & 281 & & 1 & & 1 & & 1 & 1 & 1 \\
\hline $1-2 \mathrm{~h} /$ day & 577 & & $\begin{array}{l}1.19 \\
(0.99- \\
1.43)\end{array}$ & & $\begin{array}{l}1.12 \\
(0.94- \\
1.33)\end{array}$ & & $\begin{array}{l}1.06 \\
(0.84- \\
1.35)\end{array}$ & $\begin{array}{l}1.0 \\
(0.84- \\
1.18)\end{array}$ & $\begin{array}{l}1.24 \\
(0.91- \\
1.70)\end{array}$ \\
\hline$<1 \mathrm{~h} /$ day & 236 & & $\begin{array}{l}1.29 \\
(1.03- \\
1.61)\end{array}$ & & $\begin{array}{l}1.18 \\
(0.95- \\
1.46)\end{array}$ & & $\begin{array}{l}1.16 \\
(0.84- \\
1.59)\end{array}$ & $\begin{array}{l}0.95 \\
(0.76- \\
1.19)\end{array}$ & $\begin{array}{l}1.02 \\
(0.65- \\
1.60)\end{array}$ \\
\hline $\begin{array}{l}\text { Domestic } \\
\text { work }^{\text {b }}\end{array}$ & 1102 & 0.44 & & 0.82 & & 0.03 & & 0.44 & 0.03 \\
\hline 0-10 h/week & 382 & & 1 & & 1 & & 1 & 1 & 1 \\
\hline $11-20 \mathrm{~h} /$ week & 459 & & $\begin{array}{l}0.87 \\
(0.75- \\
1.02)\end{array}$ & & $\begin{array}{l}0.92 \\
(0.79- \\
1.07)\end{array}$ & & $\begin{array}{l}0.78 \\
(0.63- \\
0.96)\end{array}$ & $\begin{array}{l}0.94 \\
(0.81- \\
1.11)\end{array}$ & $\begin{array}{l}0.79 \\
(0.59- \\
1.04)\end{array}$ \\
\hline$\geq 21 \mathrm{~h} /$ week & 261 & & $\begin{array}{l}0.95 \\
(0.80- \\
1.14)\end{array}$ & & $\begin{array}{l}0.98 \\
(0.83- \\
1.17)\end{array}$ & & $\begin{array}{l}0.74 \\
(0.55- \\
0.99)\end{array}$ & $\begin{array}{l}0.94 \\
(0.77- \\
1.14)\end{array}$ & $\begin{array}{l}0.66 \\
(0.46- \\
0.93)\end{array}$ \\
\hline $\begin{array}{l}\text { Physical } \\
\text { exercise }^{\text {b }}\end{array}$ & 1107 & 0.94 & & 0.57 & & 0.50 & & 0.55 & 0.17 \\
\hline $\begin{array}{l}\text { Twice a week } \\
\text { or more }\end{array}$ & 807 & & 1 & & 1 & & 1 & 1 & 1 \\
\hline Once a week & 153 & & $\begin{array}{l}1.01 \\
(0.85- \\
1.21)\end{array}$ & & $\begin{array}{l}0.98 \\
(0.83- \\
1.17)\end{array}$ & & $\begin{array}{l}0.96 \\
(0.72- \\
1.26)\end{array}$ & $\begin{array}{l}1.04 \\
(0.85- \\
1.26)\end{array}$ & $\begin{array}{l}0.81 \\
(0.56- \\
1.18)\end{array}$ \\
\hline $\begin{array}{l}\text { Occasionally } \\
\text { or never }\end{array}$ & 147 & & $\begin{array}{l}1.01 \\
(0.82- \\
1.25)\end{array}$ & & $\begin{array}{l}0.95 \\
(0.77- \\
1.16)\end{array}$ & & $\begin{array}{l}0.88 \\
(0.63- \\
1.22)\end{array}$ & $\begin{array}{l}1.03 \\
(0.84- \\
1.27)\end{array}$ & $\begin{array}{l}0.79 \\
(0.52- \\
1.21)\end{array}$ \\
\hline \multicolumn{10}{|c|}{ a The frequency of musculoskeletal pain in the different body regions are given in Table 1.} \\
\hline \multicolumn{10}{|c|}{ b Overall $p$-values are given as continuous variable } \\
\hline
\end{tabular}




\begin{tabular}{|c|c|c|c|c|c|c|}
\hline & & Neck $(N=956)$ & $\begin{array}{l}\text { Shoulders }(N= \\
945)\end{array}$ & $\begin{array}{l}\text { Hands }(\mathbf{N}= \\
963)\end{array}$ & $\begin{array}{l}\text { Lower back (N } \\
=956)\end{array}$ & Feet $(N=966)$ \\
\hline Daily smokers & 1111 & 0.02 & 0.17 & 0.43 & 0.34 & 0.12 \\
\hline no & 1063 & 1 & 1 & 1 & 1 & 1 \\
\hline yes & 48 & $\begin{array}{l}0.59 \\
(0.37- \\
0.92)\end{array}$ & $\begin{array}{l}0.77 \\
(0.53 \\
(1.12)\end{array}$ & $\begin{array}{l}0.83 \\
(0.53- \\
1.31)\end{array}$ & $\begin{array}{l}1.15 \\
(0.86- \\
1.53)\end{array}$ & $\begin{array}{l}0.63 \\
(0.36- \\
1.13)\end{array}$ \\
\hline $\begin{array}{l}\text { Occupational } \\
\text { category }{ }^{c}\end{array}$ & 1115 & 0.02 & $<.001$ & 0.39 & 0.01 & 0.02 \\
\hline Teacher & 246 & 1 & 1 & 1 & 1 & 1 \\
\hline $\begin{array}{l}\text { Anaesthetic } \\
\text { nurse }\end{array}$ & 214 & $\begin{array}{l}0.86 \\
(0.66- \\
1.11)\end{array}$ & $\begin{array}{l}1.03 \\
(0.81- \\
1.32)\end{array}$ & $\begin{array}{l}0.89 \\
(0.59- \\
1.35)\end{array}$ & $\begin{array}{l}0.8 \\
(0.60- \\
1.07)\end{array}$ & $\begin{array}{l}0.65 \\
(0.40- \\
1.06)\end{array}$ \\
\hline Theatre nurse & 209 & $\begin{array}{l}1.08 \\
(0.83- \\
1.41)\end{array}$ & $\begin{array}{l}1.08 \\
(0.84- \\
1.39)\end{array}$ & $\begin{array}{l}1.03 \\
(0.7- \\
1.53)\end{array}$ & $\begin{array}{l}1.20 \\
(0.93- \\
1.56)\end{array}$ & $\begin{array}{l}0.68 \\
(0.42- \\
1.09)\end{array}$ \\
\hline $\begin{array}{l}\text { Assistant } \\
\text { nurse }\end{array}$ & 224 & $\begin{array}{l}0.99 \\
(0.76- \\
1.29)\end{array}$ & $\begin{array}{l}1.07 \\
(0.84- \\
1.36)\end{array}$ & $\begin{array}{l}1.19 \\
(0.83- \\
1.70)\end{array}$ & $\begin{array}{l}1.08 \\
(0.85- \\
1.38)\end{array}$ & $\begin{array}{l}0.72 \\
(0.48- \\
1.08)\end{array}$ \\
\hline Sonographer & 222 & $\begin{array}{l}1.21 \\
(0.97- \\
1.5)\end{array}$ & $\begin{array}{l}1.44 \\
(1.18- \\
1.78)\end{array}$ & $\begin{array}{l}1.18 \\
(0.84- \\
1.67)\end{array}$ & $\begin{array}{l}1.22 \\
(0.95- \\
1.57)\end{array}$ & $\begin{array}{l}0.40 \\
(0.23- \\
0.69)\end{array}$ \\
\hline \multicolumn{7}{|c|}{ a The frequency of musculoskeletal pain in the different body regions are given in Table 1.} \\
\hline \multicolumn{7}{|c|}{ b Overall p-values are given as continuous variable } \\
\hline
\end{tabular}

Complaints on the computer work station arrangement was a risk factor for pain in the neck and the shoulders (Table 3), but these associations declined in the adjusted multi-exposure model (Table 4).

A high sum-score of psychosocial factors at baseline was a risk factor of pain in the neck, the shoulders, the hands and the lower back (Table 3). When adjusting for pain at baseline, the psychosocial factors remained as a statistically significant risk factor or for pain in the neck and the shoulders (Table 4).

High age was of importance for subsequent pain in the hands and the feet (Table 3). However, when adjusting for pain at baseline the statistically significant association remained for feet pain only (Table 4).

A high body-mass index was of importance for pain in the feet in the multi exposure model (Table 3), but the association was no longer statistically significant after adjustments for foot pain at baseline (Table 4).

Lack of time for personal recovery was a risk factor for pain in the neck and the shoulders (Table 3), but in the adjusted multi-exposure model, it remained significant for neck pain only (Table 4). 
Among the other life-style factors, a low frequency of physical exercise and much domestic work, respectively, did not predict pain in any anatomical site (Table 3 and 4). On the contrary, much domestic work was a protective factor for pain in the hands and the feet (Table 4). Further, daily smoking at baseline was a protective factor for neck pain in both multiexposure models (Table 3 and 4).

For all of the specific anatomical sites, pain at baseline was the strongest risk factor for pain in that anatomical site at follow-up, with PRs ranging from 2.4 to 4.2 between the sites; Table 4).

After adjustments of all studied occupational and personal factors, and pain at baseline, there was a residual of unknown factors associated with the occupational category, which were of importance for all of the anatomical pain-sites at followup (Table 3 and 4). Among the specific occupational categories, it was observed that among sonographers there was an increased risk of shoulder pain, but a decreased risk of pain in the feet, when pain at baseline was taken into account (Table 4).

\section{Discussion}

Principal findings

Adverse ergonomic- and psychosocial factors at baseline were risk factors for multisite pain at follow-up, with statistically significant associations in the single- multi- and adjusted multi-exposure models. However, the strongest risk factor for multisite pain at follow-up was multisite pain at baseline. Further, unknown factors associated with occupational category were of importance for multisite pain, in all of the three statistical models.

In the adjusted multi-exposure models, different risk factors were found for subsequent single-site pain in the five anatomical regions: A high sum-score of ergonomic factors at baseline was a risk factor for pain in the neck, the hands, and the feet. A high sum-score of psychosocial factors was of importance for pain in the neck and the shoulders. Moreover, lack of personal recovery was a risk factor for neck pain, and high age was a risk factor for pain in the feet. Unexpected findings were that much domestic work was a protective factor for hand- and foot pain, and that daily smoking was a protective factor for neck pain. For all of the specific anatomical sites, the strongest risk factor of pain at follow-up was pain in the actual site at baseline. Further, the occupational category was of importance for pain in the neck, the shoulders, the lower back and the feet at follow-up.

Several of the demonstrated relationships found in the multi-exposure analyses became less strong when the models were adjusted for pain at baseline. This indicate that an important part of the associations were present already at baseline.

Strengths and weaknesses of the study

A strength of the study is the longitudinal study design, and that we used common and tested indicators for physical and psychosocial working conditions. Another advantage is the outcome measure of pain that comprise a combination of the frequency and intensity of complaints of a certain dignity, on the individual level. Thus, mild complaints which do not interfere with daily life activities were not included as an outcome. The fact that the study population included women in common professions from in total 116 different workplaces in Sweden is also a strength, as it increases the generalizability of the study.

The participants at follow-up and the drop-outs reported, with a few exceptions, similar frequencies of pain at baseline. Thus, we do not believe that the overall selection of participation at follow-up has had a significant impact on the longitudinal results.

An obvious limitation of this longitudinal study was that all data were self-reported. Further, we only had two assessment rounds with quite a long separation in time. Thus we could not identify any potential changes that may have occurred

Page $21 / 28$ 
between the two measurements. As pain includes all pain episodes during the 12-months period preceding the reporting time, this should have a limited influence on results.

Another limitation was that the data collection, at both baseline and follow-up, went on for an extended period of time. This was due to administration of the high number of different work places, and that time-consuming assessments (objective measurements of the physical workload and clinical examinations) were performed in subgroups at baseline [19]. However, at both baseline and follow-up, we administered the questionnaires alternately to the teachers, the surgical staff and the sonographers. Thus, any societal changes that may have occurred during this time period would affect the occupational groups similarly. Consequently, the mean follow-up period was about as long in the five occupational groups, although there was a large variation between the workplaces and between the participants. This variation in follow-up periods may have influenced the results. However, the correlation between the length of follow-up and change in multisite pain was very low (rho 0.03) and thus we believe that this was not a major problem.

For the multi-exposure models, sum scores of ergonomic and psychosocial factors were created, to obtain a gradually increasing effect of several ergonomic- and psychosocial factors, respectively. The underlying assumption was that the experience of two or more adverse ergonomic or psychosocial dimensions is worse than the experience of none or only one such dimension.

The results in relation to other studies

The present study population comprises women with contrasting occupational exposures. The work tasks among the surgical staff (i.e. anaesthetic-, theatre- and assistant nurses) include physical exertions when handling of patients and equipment, and prolonged twisted and static postures during surgery [28]. The work tasks among the sonographers is to a high extent characterized by prolonged sitting in constrained postures [29]. In contrast, the physical workload among the teachers is varied and physically relatively light. While time-pressure and adverse psychosocial working conditions may be present in all of the five occupational groups, the mental strain is particularly high among the teachers [19, 30, 31]. Hence, these occupational groups were exposed to working conditions that previously have been recognized as risk factors for musculoskeletal pain, concerning ergonomic- $[4,32,33]$ and psychosocial factors [8-9]. Thus, in the present study of nurses, teachers and sonographers, the scientific evidence of both ergonomic- and psychosocial factors as risk factors for musculoskeletal pain, was confirmed.

A clear finding of the study was that pain at baseline vas the strongest risk factor for the occurrence of pain at follow-up. Similar results of previous pain episodes as predictors of present pain have been reported previously [34, 35]. However, pain was associated with several occupational factors already at baseline [19]. Thus, since many had worked for a long time (mean seniority 17 years) they may have developed work-related pain already prior to the baseline study, which remained (or recurred) at follow up. Of course, persistent pain may also be due to individual susceptibility or other non-work-related factors. Thus, to explore associations between occupational and personal risk factors, and changes in pain during the follow-up period, we adjusted for pain at baseline and found longitudinal effects also of adverse ergonomic conditions and psychosocial factors.

Among the personal and life-style factors, only a few factors were of importance for subsequent single- and multisite pain. The prevalence of musculoskeletal pain is commonly believed to increase at higher age $[1,35]$ but in the present study this was only the case for pain in the hands and the feet. High age did not explain multisite pain. A high body mass index was of importance for pain in the feet, and for multisite pain. However, most likely, since the statistical significances disappeared after adjustment for pain at baseline, those associations were present already at baseline. Further, lack of personal recovery was a risk factor for pain in the neck and shoulders. Unexpectedly, much domestic work at baseline was found to be a protective factor for pain in the hands and the feet at follow up. We have no explanation for this, but a speculation is that participants with persistent pain from hands or feet need more rest after work, and thus avoid to perform much domestic work. Further, since hand- and foot pain was explained by increasing age (in the second model), 
another possible explanation is that older participants no longer have small children living at home, and thus have less need for domestic work. Daily smoking is considered to be a risk factor for poor health, including musculoskeletal pain [13]. Contrary, we found that daily smoking was a protective factor for neck pain. Smokers may take more frequent breaks at work, which may be beneficial in relation to work-related pain. However, very few participants (4\%) were daily smokers, and it cannot be ruled out that the protective effect was as a random finding.

A general finding was the patterns of ergonomic- and psychosocial factors as risk factors for both multisite- and single-site pain. These findings were consistent with the study of Herin et al. 2014 [36]. Further, as in the study of Coggon et al 2013 [35], our results points to an incremental increase of the associations (as illustrated in Figs. 2 and 3); the more adverse ergonomic and psychosocial working conditions reported at baseline, the higher the number of pain-sites at follow-up.

There was a large fluctuation in number of sites of pain between baseline and follow-up. About one third reported an increased number of pain-sites at follow-up, indicating a worsened condition. Fortunately, almost as many reported less pain-sites at follow-up and thus improved health in this regard. Thus, for many individuals, the occurrence of pain is not a static condition, it rather reflects a pattern of recurrence $[15,16]$. Nevertheless, in spite of the strict criteria, multiple painsites were common in the present study population. Almost one fifth (18\%) reported persistent multisite pain, i.e. $\geq$ four pain-sites at both baseline and follow-up. It is notable that only $11 \%$ did not report pain in any anatomical site, neither at baseline nor at follow-up. As far as we know, our outcome-measure of pain has not previously been used in scientific studies of multisite pain, thus making direct comparisons difficult. However, a longitudinal study of Finnish food company workers reported that $36 \%$ of the study population (involving an unclear distribution of women and men) had "no pain" [19]. The high numbers of affected workers in the present study is worrying, since the study population was taken from ordinary occupations, which constitute a large proportion of the female labour force in Sweden. There is no reason to believe that we have caught any particularly loaded/burdened groups among these occupations, as we have studied personnel in many different work-sites. Rather, factors associated with the organizational climate [37], such as time pressure and high physical/mental demands, may contribute to the disorders since such conditions affect both the physical and psychosocial working conditions.

\section{Conclusoins}

An overwhelming majority of the women in these common occupations were affected by musculoskeletal pain, from one or several body regions. Further, a substantial proportion of the women were classified as having persistent multisite pain. Since the present criteria of pain was rather strict, the reported impaired health conditions should not be overlooked. Among the occupational factors, both ergonomic- and psychosocial factors were of importance for specific pain-sites, as well as for multisite pain. The findings are important for preventive strategies, and points to the need of improved work environment, with actions on individual, organizational and societal level.

\section{List Of Abbreviations}

AnN Anaesthetic nurses

AsN Assistant nurses

BMI Body Mass Index

MEI Mechanical exposure index

PHYI Physical exposure index

Sg Sonographers

Page 23/28 
Te Teachers

TN Theatre nurses

\section{Declarations}

\section{Ethics approval and consent to participate}

Written informed consent for participation was obtained from all participants. The regional ethics committee at Lund University approved the study (March 10 2010; reference no. 2010/19).

\section{Consent for publication}

Not applicable

\section{Availability of data and material}

As the database referred to in this manuscript contains direct or indirect identifiers, it is not available in an open access repository, as there is a possibility that the participants may not be completely anonymous. Readers interested in exploring the data should contact the corresponding author.

\section{Competing interests}

The authors declare that they have no competing interests.

\section{Funding}

This paper was supported by the Swedish Council for Working Life and Social Research (FAS), the Medical Faculty of Lund University and the County Councils of Southern Sweden. The sponsors had no further role in the design of the study and collection, analysis, and interpretation of data and in writing the manuscript.

\section{Authors' contribution}

$\mathrm{IA}, \mathrm{JB}$ and $\mathrm{CN}$ and were responsible for concept and design. IA carried out the data collection and performed the analyses. JB was responsible for the statistical analyses. IA, JGR, AL, JB and $C N$ were responsible for the interpretation of the results and helped to draft the manuscript. All authors have read and approved the final manuscript.

\section{Acknowledgements}

Skilful technical assistance was given by Ms Anna Larsson and Ms Charlotte Löfqvist. We are also grateful to the nurses, teachers and sonographers for their keen participation.

\section{Additional Files}

\section{Additional files}

Additional table 1. Results from single exposure models regarding the separate dimensions included in the sum-scores of ergonomic- and psychosocial factors

Additional table 2. Single-exposure models of risk factors for single-site pain

\section{References}


1. Kinge JM, Knudsen AK, Skirbekk V, Vollset SE. Musculoskeletal disorders in Norway: prevalence of chronicity and use of primary and specialist health care services. BMC Musculoskeletal Disorders 2015;16;75.

2. Oranye NO and Benett J. Prevalence of work-related musculoskeletal and non-musculoskeletal injuries in health care workers: the implications for work disability management. Ergonomics 2018;61(3):355-366.

3. Balogh I, Arvidsson I, Björk J, Hansson G-Å,et al. Work-related neck and upper limb disorders - quantitative exposureresponse relationships adjusted for personal characteristics and psychosocial conditions. BMC Musculoskeletal Disorders 2019;20:139.

4. van der Molen HF, Foresti C, Daams JG, Fring -Diesen M, et al. Work-related risk factors for specific shoulder disorders:a systematic review and meta-analysis. Occup Environ Med 2017;74 (10):745-755.

5. Dalbøge A, Frost P, Andersen JH, Svendsen SW. Cumulative occupational shoulder exposures and surgery for subacromial impingement syndrome: a nationwide Danish cohort study. Occup Environ Med. 2014;71(11):750-6.

6. Bach Lund C, Mikkelsen S, Caspar Thygesen L, Hansson G-Å, et al. Movements of the wrist and the risk of carpal tunnel syndrome: a nationwide cohort study using objective exposure measurements. Occup Environ Med 2019;76(8)519-526.

7. Hanvold TN, Waersted M, Mengshoel AM, et al. The effect of work-related sustained trapezius muscle activity on the development of neck and shoulder pain among young adults. Scand J Work Environ Health 2013;39(4):390-400.

8. Gerr F, Fethke NB, Anton D, Merlino L, et al. A prospective study of musculoskeletal outcomes among manufacturing workers: Il. Effects of psychosocial stress and work organization factors. Hum Factors 2014;56 (1):178-90.

9. Kraatz S, Lang J, Kraus T, Münster E, Ochsmann E. The incremental effect of psychosocial workplace factors on the development of neck and shoulder disorders: a systematic review of longitudinal studies. Int Arch Occup Environ Health 2013;86 (4):375-95.

10. Bernal D, Campos-Serna J, Tobias A, Vargas-Prada S, et al. Work-related psychosocial risk factors and musculoskeletal disorders in hospital nurses aides: a systematic review and meta-analysis. Int J Nurs Stud 2015; 52 (2):635-48.

11. Ballester Arias AR, Garcia AM. Occupational exposure to psychosocial factors and presence of musculoskeletal disorders in nursing staff: A review of studies and meta-analysis. Rev Esp Salud Publica 2017;7:91.

12. Buscemi V, Chang WJ, Liston MB, McAuley JH et al. The role of Perceived stress and life stressors in the development of chronic muskuloskeletal pain disorders:A systematic review. J Pain doi: 10.1016/j.jpain.2019.02.008. [Epub ahead of print]

13. Viikari-Juntura E, Martikainen R, Luukkonen R, Mutanen P, Takala E, Riihimaki H. Longitudinal study on work related and individual risk factors affecting radiating neck pain. Occup Environ Medicine 2001;58 (5) 345-52.

14. Miranda H, Viikari-Juntura E, Martikainen R, Takal E-P, Riihimäki H. A prospective study of work related factors and physical exercise as predictors of shoulder pain. Occup Environ Med 2001;58:528-534.

15. Luime JJ, Koes BW, Miedem HS, Verhaar JAN, Burdorf A. High incidence and recurrence of shoulder and neck pain in nursing home employees was demonstrated during a 2-year follow-up. J Clinical Epidemiology 2005;58:407-13.

16. Neupane S, Leino_Arjas P, Nygård C, Oakman J, Virtanen P. Development pathways of multisite musculoskeletal pain: what is the influence of physical and psychosocial working conditions? Occup Environ Med 2017;74 (7):468-475.

17. Pereira de Fernandes R, Burdorf A. Associations of multisite pain with healthcare utilization, sickness absence and restrictions at work. Int Arch Occup Environ Health 2016;89:1039-1046.

18. Gerr F, Fethke NB, Merlino L, Anton D, et al. A prospective study of musculoskeletal outcomes among manufacturing workers: I. Effects of physical risk factors. Hum factors 2014;56(1):112-30

19. Arvidsson I, Gremark Simonsen J, Dahlqvist C, Axmon A, Karlson B, Björk J, Nordander C. Cross-sectional associations between occupational factors and musculoskeletal pain in women teachers, nurses and sonographers. BMC Musculoskeletal Disorders 2016;17:35.

Page 25/28 
20. Balogh I, Ǿrbaek P, Winkel J, Nordander C, Ohlsson K, Andersen JE, Malmö Shoulder Neck Study Group. Questionnairebased mechanical exposure indices for large population studies - reliability, internal consistency and predictive validity. Scand J Work Environ Health 2001;27:41-48.

21. Kristensen TS, Hannerz H, Hogh A, Borg V. The Copenhagen Psychosocial Questionnaire - a tool for the assessment and improvement of the psychosocial work environment. Scand J Work Environ Health 2005;31:438-49.

22. Karasek R, Theorell T. Healthy Work Stress, productivity and the reconstruction of Working Life. Harper Collins, USA 1990.

23. Karasek R, Brisson C, Kawakami N, Houtman I, Bongers P, Amick B. The Job Content Questionnaire (JCQ): an instrument for internationally comparative assessments of psychosocial job characteristics. J Occup Health Psychol 1998;3:322-55.

24. Kourinka I, Jonsson B, Kilbom Å, Vinterberg H, Andersson G, Jørgensen K. Standardized Nordic questionnaires for the analysis of musculoskeletal symptoms. Appl Ergon. 1987;18: 233

25. Karlqvist LK, Härenstam A, Leijon O, Scheele P. Excessive physical demands in modern worklife and characteristics of work and living conditions at risk. Scand J Work Environ Health 2003;29(5):363-77.

26. Holmström E, Moritz U.Low back pain - correspondence between questionnaire, interview and clinical examination. Scand J Rehab Med. 1991;23, 119-25.

27. Borg G. Psychophysical scaling with applications in physical work and the perception of exertion. Scand J Work Environ Health 1990;16 Suppl 1:55-8.

28. Carugno M, Pesatori AC, Ferrario MM, Ferrari AL, et al. Physical and psychosocial risk factors for muskuloskeletal disorders in Brazilian and Italian nurses. Cad Saude Publica 2012;28(9):1632-1642.

29. Gremark Simonsen J, Dahlqvist C, Enquist H, Nordander C, Axmon A, Arvidsson I. Assessments of physical workload in sonography tasks using inclinometry, goniometry and electromyography. Safety and Health at Work. 2018;3:326-33.

30. Arvidsson I, Leo U, Larsson A, Håkansson C, Persson R, Björk J. Burnout among school teachers: quantitative and qualitative results from a follow-up study in southern Sweden. BMC public Health 2019;19:655.

31. Hakanen JJ, Bakker AB, Schaufeli WB. Burnout and work engagement among teachers. J School Psychol. 2006;43:495-513.

32. Østensvik T, Veiersted KB, Nilsen P. A method to quantify frequency and duration of sustained low-level muscle activity as a risk factor for musculoskeletal discomfort. J Electromyogr Kinesiol 2009 Apr;19(2):283-94.

33. Sterud T, Johannessen HA, Tynes T. Work-related psychosocial and mechanical risk factors for neck/shoulder pain: a 3-year follow-up study of the general working population in Norway. Int Arch Occup Environ Health 2014;87(5):471-81.

34. Papageorgiou AC, Croft PR, Ferry S, Jayson MI, Silman AJ. Influence of previous pain experience on the episode incidence of low back pain: Results from the South Manchester Back Pain Study. Pain 1996;66(2-3):181-5.

35. Coggon D, Ntani G, Palmer KT, Felli VE, et al. Patterns of multisite pain and associations with risk factors. Pain 2013;154:1769-1777.

36. Herin F, Vezina M, Thaon I, Soulat JM, Paris C, ESTEV group. Predictive risk factors for regional and multisite musculoskeletal pain: a 5-year prospective study in a working population. Pain 2014;155(5):937-43.

37. Gershon RRM, Stone PW, Zeltser M, Faucett J,et al. Organizational climate and nurse health outcomes in the United States: a systematic review. Industrial Health 2007;45:622-636.

\section{Figures}




\begin{tabular}{|c|c|c|c|c|c|c|c|}
\hline \multirow[b]{2}{*}{ FOLLOW-UP } & \multicolumn{2}{|r|}{ Total } & \multicolumn{5}{|c|}{ BASELINE } \\
\hline & $\geq$ Four sites & 288 & 9 & 21 & 25 & 51 & 182 \\
\hline & Three sites & 173 & 16 & 31 & 42 & 35 & 49 \\
\hline & Two sites & 176 & 32 & 31 & 47 & 46 & 20 \\
\hline & One site & 184 & 65 & 51 & 46 & 10 & 12 \\
\hline & No pain & 219 & 117 & 46 & 31 & 18 & 7 \\
\hline & & & No pain & One site & Two sites & Three sites & $\geq$ Four sites \\
\hline & & Total & 239 & 180 & 191 & 160 & 270 \\
\hline & $\begin{array}{c}\text { No pain } \\
N=117(11 \%)\end{array}$ & $\begin{array}{r}\text { Unchang } \\
\mathrm{N}=13\end{array}$ & $\begin{array}{l}\text { d } 1-3 \text { sites } \\
(13 \%)\end{array}$ & $\begin{array}{r}\text { Persistent } \\
\mathrm{N}=18\end{array}$ & $\begin{array}{l}\text { ultisite pain } \\
(18 \%)\end{array}$ & $\begin{array}{c}\text { Increased } \\
\mathrm{N}=323(31 \%)\end{array}$ & $\begin{array}{c}\text { Decreased } \\
\mathrm{N}=285(27 \%)\end{array}$ \\
\hline
\end{tabular}

\section{Figure 1}

Cross-tabulation of the number of anatomical sites with pain among the participants at baseline and at follow-up $(n=1040)$.

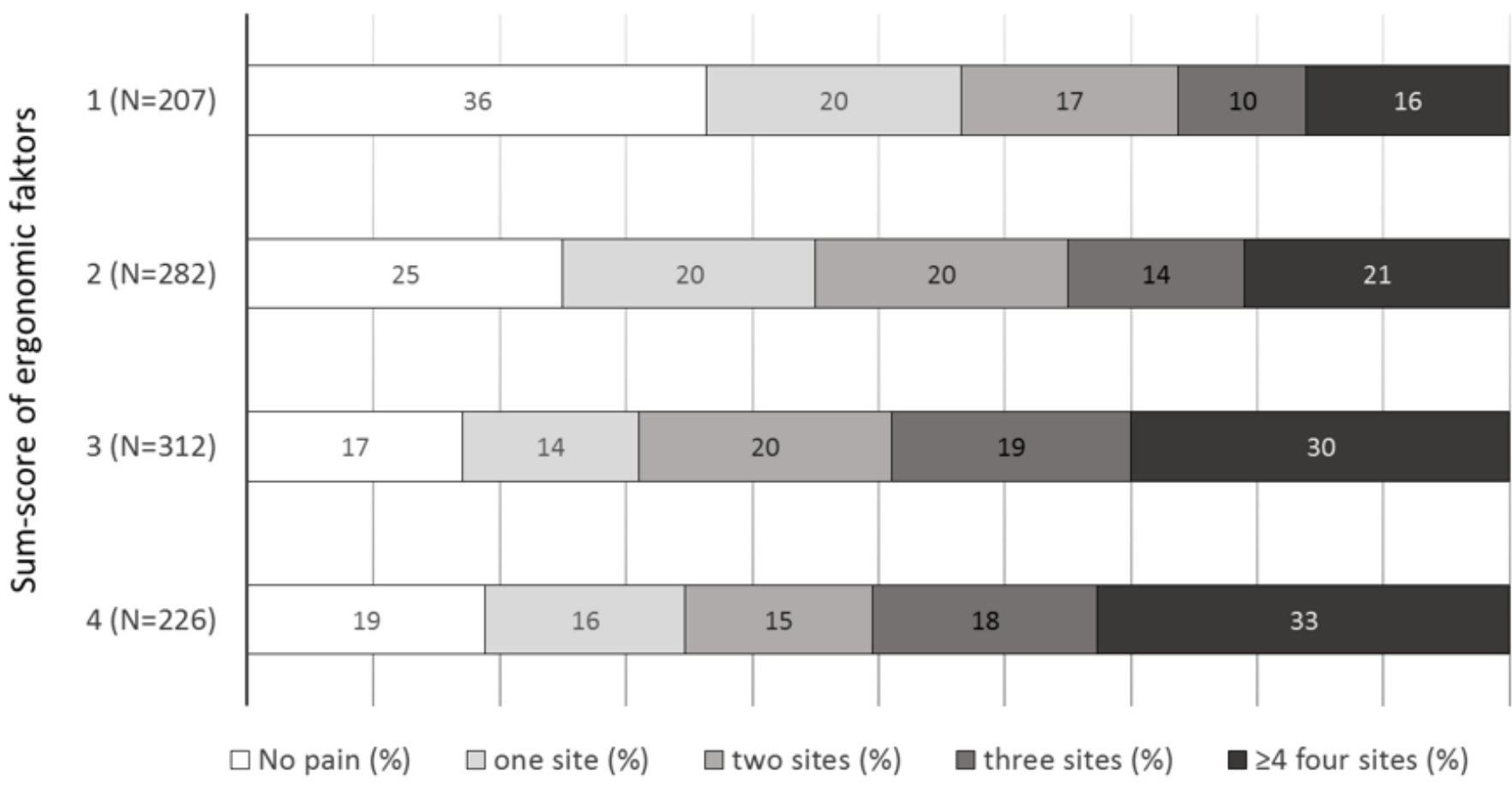

Figure 2

The association between sum score of ergonomic factors (1-4) at baseline and number of anatomical sites with pain at follow. 


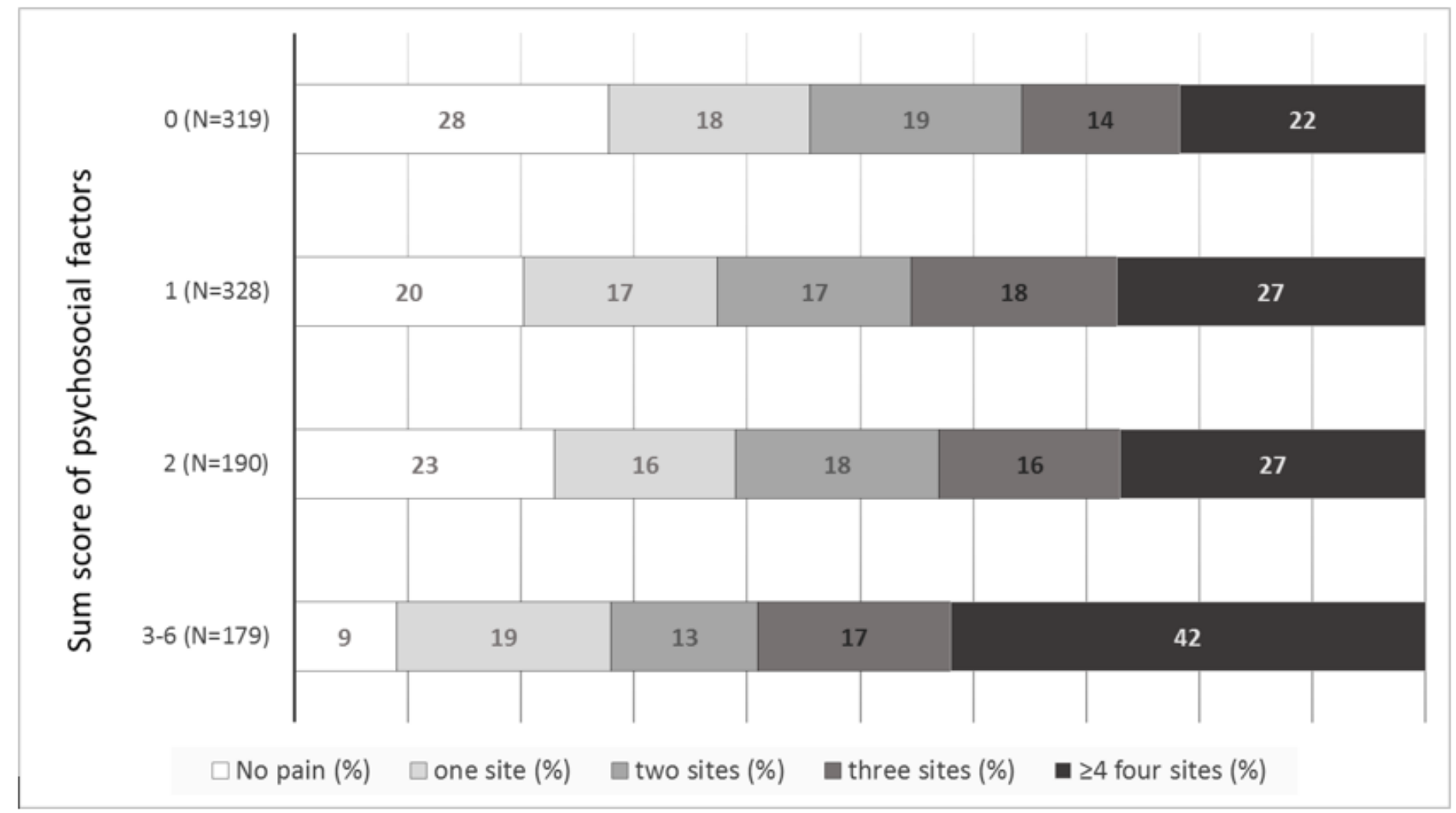

Figure 3

The association between sum score of psychosocial factors $(0,1,2$ and 3-5) at baseline and number of anatomical sites with pain at follow.

\section{Supplementary Files}

This is a list of supplementary files associated with this preprint. Click to download.

- Additionaltable2.docx

- Additionaltable1.docx 